\title{
Development of a New Empirical Relation to Assess P-wave Velocity Anisotropy of Rocks
}

Hassan Moomivand ( $\nabla$ h.moomivand@urmia.ac.i )

Urmia University https://orcid.org/0000-0002-6106-9779

Hussamuddin Moomivand

Amirkabir University of Technology

Rain Nikrouz

Urmia University

Rashid Azad

Urmia University

\section{Research Article}

Keywords: P-wave velocity, anisotropy, rock, schist, shale, new relation

Posted Date: May 19th, 2021

DOI: https://doi.org/10.21203/rs.3.rs-459336/v1

License: (9) This work is licensed under a Creative Commons Attribution 4.0 International License. Read Full License

Version of Record: A version of this preprint was published at Geotechnical and Geological Engineering on October 19th, 2021. See the published version at https://doi.org/10.1007/s10706-021-01983-w. 


\title{
Development of a new empirical relation to assess P-wave velocity anisotropy of rocks
}

\author{
Hassan Moomivand ${ }^{\mathrm{a}^{*}}$.Hussamuddin Moomivand ${ }^{\mathrm{b}}$. Ramin Nikrouz ${ }^{\mathrm{c}}$. Rashid Azad ${ }^{\mathrm{d}}$ \\ $\mathrm{a}^{*}$ Associate professor of Rock Mehanics, Urmia University, Urmia, Iran, ORCID: 0000-0002-6106-9779, \\ h.moomivand@urmia.ac.ir (Corresponding author) \\ ${ }^{b} \mathrm{MSc}$ in Rock Mehanics, Amirkabir University of Technology (Tehran Polytechnic), Tehran, Iran \\ ${ }^{c}$ Associate professor of Geophysics, Urmia University, Iran \\ ${ }^{\mathrm{d}} \mathrm{MSc}$ in Geophysics, Urmia University, Iran,
}

\begin{abstract}
Wave velocity as a simple nondestructive method is used for various applications in geotechnical engineering. Several physical parameters and anisotropy related to rock textural arrangements, schistosity and weakness planes such as cracks and joints affect the P-wave velocity $\left(\mathrm{V}_{\mathrm{P}}\right)$. First, $\mathrm{V}_{\mathrm{P}}$ anisotropy of quartz-mica schist as a common type of widespread metamorphic rock was compared with $V_{P}$ anisotropy of jointed homogeneous limestone specimens to clarify effect of these two different types of anisotropies. The results showed that the $V_{P}$ anisotropy of quartz-mica schist texture is stronger than the $\mathrm{V}_{\mathrm{P}}$ anisotropy of jointed limestone, because all body of quartz-mica schist specimens have $\mathrm{V}_{\mathrm{P}}$ anisotropy behavior. Many rocks are anisotropic and degree of anisotropy varies from one rock to another. Several investigations have been carried out on $V_{P}$ anisotropy but there is not a unique comprehensive relation to represent the influence of different degrees of anisotropy on the $\mathrm{V}_{P}$ for different rocks. The relation between $\mathrm{V}_{\mathrm{P}}$ and angle $(\theta)$ between the axis of symmetry (perpendicular to weakness planes) with the wave propagation direction was analyzed for a wide range of anisotropy degree using the results of nine different types of rocks including: Angouran quartz-mica schist, Golgohar mica schist, amphibole schist, mica-quart schist, Marcellus shale, Withby shale WUK47B, WUK70 and WUK2, and Veroia-Polymylos gneiss. A new simple empirical relation fitted to all groups of results was obtained to assess $\mathrm{V}_{\mathrm{P}}$ for different degrees of anisotropies with a good correlation of determination $\left(\mathrm{R}^{2}\right.$ $=0.937)$, low RMSE $(\mathrm{RMSE}=320 \mathrm{~m} / \mathrm{s})$ and low $\mathrm{CV}(\mathrm{CV}=7.0 \%)$. P wave velocity anisotropy can simply be predicted by the developed relation using only two parameters of $\mathrm{V}_{\mathrm{P} 0}$ and $\mathrm{V}_{\mathrm{P} 90}$. $\mathrm{A} \mathrm{V}_{\mathrm{P}}$ anisotropy classification diagram was also developed based on the different values of $\varepsilon$.
\end{abstract}

Keywords: P-wave velocity, anisotropy, rock, schist, shale, new relation.

\section{Introduction}

Seismic waves are called elastic waves of materials, as these waves cause elastic transformation of materials. When passing through the rocks, these waves cause material transformation and the velocity of transformation process varies in different rocks depending on their physical and mechanical properties. A seismic wave propagates outwards from a seismic source at a velocity determined by the physical and mechanical properties of the surrounding rocks. The wave velocity through a homogeneous rock is the same in all directions away from the source. Seismic wave travelling 
along ray paths that, in isotropic media, are everywhere perpendicular to wavefronts, but the wave velocity varies from one direction to another in an anisotropic media. Anisotropy in rocks may be either inherent, induced or both (Ramamurthy, 2008). Wave velocity anisotropy comes intrinsically from the lattice-preferred orientations of rockforming crystals and their textural arrangements (Babuška, 1981; Ben Ismaïl and Mainprice, 1998) and weakness planes such as schistosity foliation, the systematic arrangement of micro cracks, fractures, joints and fault zones that are induced by deviatoric stresses and may have a secondary effect on the anisotropy of rocks (Anderson et al., 1974; Nur, 1971; Song and Suh, 2014). The distortional deformations that result from tectonic and orogenic movements can also be the sources of wave velocity anisotropy (Kern, 1978).

Seismic anisotropy has been studied more frequently by researchers to enhance seismic data interpretation and petrophysical properties evaluation of the subsurface rocks. In metamorphic rocks, foliation is an important parameter to produce seismic anisotropy. P-wave seismic data show anisotropy effects that are often difficult to attribute convincingly to anisotropy (Winterstein, 1990).

P-wave propagation within the metamorphic rocks are usually in directions not parallel to inherent rock symmetry because of texture and structure and/or oblique-to-accurate ray paths. To have information about the effects of seismic velocity anisotropy on seismic wave propagation in the Earth's crust and better understanding of how some parameters control the ultrasonic characteristics of rock mass, laboratory scale seismic measurements are needed (Takanashi et al. 2001; Kim et al. 2012). Laboratory studies show that there is a good relation between the seismic P-wave velocity and foliation orientation (Tatham 1982; Takanashi et al. 2001; Palmer 2001). It is possible to have detailed information on wave propagation by measuring seismic anisotropy velocities of all directions in rocks (Takanashi et al. 2001). It should be noted that measurements of P-wave velocity anisotropy in one plane give a little information about the anisotropic structure of a refractor (Backus 1962; Crampin and Bamford 1977; Crampin et al. 1980; Crampin and Kirkwood 1981). In recent years, the behavior of transversely isotropic rocks, e.g., gneiss, schist, slate, phyllite, shale, mudstone, and layered sandstone, has attracted increased attention (Cardenes et al. 2021; Xu et al. 2017; Li et al. 2017; Sarout and Gueguen 2008; Barton 2007). The anisotropy is one of the most distinct features that must be considered in this kind of rock, and is widely encountered in civil, mining, petroleum, geothermal, and geoenvironmental engineering (Ma et al., 2018).

Nowadays, applications of nondestructive method such as ultrasonic wave velocities have increased progressively in geotechnical projects (Wang et al. 2020; Heidari et al. 2020; Liu et al. 2021). These methods are performed to obtain direct information of rock quality and other physical - dynamic and geodynamic parameters. Experimental study on physical and mechanical characteristics of rocks and relationship between these parameters improve understanding of geophysical and petrophysical data (Patella and Patella 2009). Seismic velocity is closely related to rock properties, which are coupled with lithological and physical parameters in a complex manner (Kern 1990; Song and Suh 2014). Many investigators have carried out to measure the $\mathrm{V}_{\mathrm{P}}$ anisotropy for various rock types (Thomsen, 1986; Barton 2007; Xu et al. 2017; Li et al. 2017; Sarout and Gueguen 2008; Rezaei et al. 2019; Cardenes et al. 2021). The wave velocity anisotropy in rocks can be approximated by simple anisotropy (Thomsen 1986) or its modification can be used as approximate method to study velocity anisotropy (Tsvankin 1997). The most common case is transverse isotropy with only one symmetry axis (denoted TI hereafter). Weak TI, P- and S-wave velocities in all directions can 
be approximated well by calculations based on Thomsen's anisotropy parameters: $\varepsilon, \gamma$ and $\delta$ (Thomsen 1986). Thomsen (1986) has also developed a relation to assess $V_{P}$ as a function of $\theta$ angle. To assess the relation between $\mathrm{V}_{\mathrm{P}}$ and $\theta$ angle using Thomsen's relation, the results of four parameters $\mathrm{V}_{\mathrm{P} 0}{ }^{\circ}, \mathrm{V}_{\mathrm{P} 90}{ }^{\circ}, \mathrm{V}_{\mathrm{S} 0}{ }^{\circ}$ and $\mathrm{V}_{\mathrm{P} 60}{ }^{\circ}$ are needed. $A$ unique comprehensive relation with a small number of parameters has not yet been given to represent the influence of different degrees of anisotropy on the $\mathrm{V}_{\mathrm{P}}$ for different rocks.

In this study, first wave velocity in isotropic and anisotropic rock media has been described. $V_{P}$ anisotropy of schistosity in quartz-mica schist as a common type of widespread metamorphic rock has been compared with $V_{P}$ anisotropy of jointed homogeneous limestone specimens to clarify the effect of these two different types of anisotropies. The relation between $V_{P}$ and $\theta$ angle have been analyzed using nine groups of results to find the parameters affecting the $V_{P}-\theta$ angle relation. This made a way to achieve a reliable simple relation to predict $V_{P}$ anisotropy by less parameters than the Thomsen's relation, and development a $V_{P}$ anisotropy classification system.

\section{Wave velocity in anisotropic rock media}

The relationship between stress $\left(\sigma_{\mathrm{xyz}}\right)$ and strain $\left(\varepsilon_{\mathrm{xyz}}\right)$ in $\mathrm{x}$, $\mathrm{y}$ and $\mathrm{z}$ directions for vertical transverse isotropic symmetry (VTI) in rock media can be written as in the matrix form follows:

$\sigma_{x y z}=C_{V I I} \varepsilon_{x y z}$

The transverse anisotropic matrix has five non-zero values distributed among 12 non-zero elements. The stiffness matrix for vertical transverse isotropic symmetry (VTI) is described by 5 independent elastic constants as follows:

$C_{V T I}=\left[\begin{array}{cccccc}C_{11} & C_{11-} C_{66} & C_{13} & 0 & 0 & 0 \\ C_{11-} C_{66} & C_{11} & C_{13} & 0 & 0 & 0 \\ C_{13} & C_{13} & C_{33} & 0 & 0 & 0 \\ 0 & 0 & 0 & C_{44} & 0 & 0 \\ 0 & 0 & 0 & 0 & C_{44} & 0 \\ 0 & 0 & 0 & 0 & 0 & C_{66}\end{array}\right]$

$\mathrm{C}_{11}, \mathrm{C}_{33}, \mathrm{C}_{44}, \mathrm{C}_{66}$ and $\mathrm{C}_{13}$ are the five elastic stiffness needed to describe a VTI media. The stiffness matrix is explained using $\mathrm{P}$ wave velocity along the foliation direction $\left(\mathrm{V}_{\mathrm{P} 90^{\circ}}\right)$, $\mathrm{P}$ wave velocity perpendicular to the foliation $\left(\mathrm{V}_{\mathrm{P} 0^{\circ}}\right), \mathrm{S}$ wave velocity along the foliation direction $\left(\mathrm{V}_{\mathrm{S} 90^{\circ}}\right)$ and $\mathrm{S}$ wave velocity perpendicular to the foliation $\left(\mathrm{V}_{\mathrm{S}^{\circ}}\right)$ as follows (Winterstein 1990): 


$$
\begin{aligned}
& C_{V T I}=\left[\begin{array}{cccccc}
\rho V_{P 90^{\circ}}^{2} & \rho\left(V_{P 90^{\circ}}^{2}-2 V_{S 90^{\circ}}^{2}\right) & C_{13} & 0 & 0 & 0 \\
\rho\left(V_{P 90^{\circ}}^{2}-2 V_{S 90^{\circ}}^{2}\right) & \rho V_{P 90^{\circ}}^{2} & C_{13} & 0 & 0 & 0 \\
C_{13} & C_{13} & \rho V_{P 0^{\circ}}^{2} & 0 & 0 & 0 \\
0 & 0 & 0 & \rho V_{S 0^{\circ}}^{2} & 0 & 0 \\
0 & 0 & 0 & 0 & \rho V_{S 0^{\circ}}^{2} & 0 \\
0 & 0 & 0 & 0 & 0 & \rho V_{S 90^{\circ}}^{2}
\end{array}\right] \\
& C_{11}=\rho V_{P 90^{\circ}}^{2} \\
& C_{33}=\rho V_{P 0^{\circ}}^{2} \\
& \mathrm{C}_{44}=\rho \mathrm{V}_{\mathrm{S} 0^{\circ}}^{2} \\
& C_{66}=\rho V_{S 90^{\circ}}^{2} \\
& C_{13}=\left[\left\{\left(2 \rho V_{P 60^{\circ}}^{2}-\frac{3}{4} C_{11}-\frac{1}{4} C_{33}-C_{44}\right)^{2}-\left(\frac{3}{4} C_{11}-\frac{1}{4} C_{33}-\frac{1}{2} C_{44}\right)^{2}\right\} \frac{3}{4}\right]^{\frac{1}{2}}-C_{44} \\
& \mathrm{C}_{13}=\left[\left\{\rho^{2}\left(2 \mathrm{~V}_{\mathrm{P} 60^{\circ}}^{2}-\frac{3}{4} \mathrm{~V}_{\mathrm{P} 90^{\circ}}^{2}-\frac{1}{4} \mathrm{~V}_{\mathrm{P}^{\circ}}^{2}-\mathrm{V}_{\mathrm{S}^{\circ}}^{2}\right)^{2}-\rho\left(\frac{3}{4} \mathrm{~V}_{\mathrm{P} 90^{\circ}}^{2}-\frac{1}{4} \mathrm{~V}_{\mathrm{PO}^{\circ}}^{2}-\frac{1}{2} \mathrm{~V}_{\mathrm{S}^{\circ}}^{2}\right)^{2}\right\} \frac{3}{4}\right]^{\frac{1}{2}}-\rho \mathrm{V}_{\mathrm{S}^{\circ}}^{2}
\end{aligned}
$$

$\rho=$ the bulk density .

Thomsen (1986) developed the quantified anisotropy of P and S waves in a VTI media using elastic constants as follows:

$$
\begin{aligned}
& \varepsilon=\frac{\mathrm{C}_{11}-\mathrm{C}_{33}}{2 \mathrm{C}_{33}}=\frac{\mathrm{V}_{\mathrm{P} 90^{\circ}}^{2}-\mathrm{V}_{\mathrm{P} 0^{\circ}}^{2}}{2 \mathrm{~V}_{\mathrm{P}^{\circ}}^{2}}=\frac{\left(\mathrm{V}_{\mathrm{P} 90^{\circ}}-\mathrm{V}_{\mathrm{P} 0^{\circ}}\right)\left(\mathrm{V}_{\mathrm{P} 90^{\circ}}+\mathrm{V}_{\mathrm{P} 0^{\circ}}\right)}{2 \mathrm{~V}_{\mathrm{P}^{\circ}}^{2}}=\frac{\left(\mathrm{V}_{\mathrm{P} 90^{\circ}}-\mathrm{V}_{\mathrm{P} 0^{\circ}}\right)}{\mathrm{V}_{\mathrm{P} 0^{\circ}}} \times \frac{\left(\mathrm{V}_{\mathrm{P} 90^{\circ}}+\mathrm{V}_{\mathrm{P}^{\circ}}\right)}{2 \mathrm{~V}_{\mathrm{P}^{\circ}}} \approx \frac{\mathrm{V}_{\mathrm{P} 90^{\circ}}-\mathrm{V}_{\mathrm{P}^{\circ}}}{\mathrm{V}_{\mathrm{P}^{\circ}}}
\end{aligned}
$$

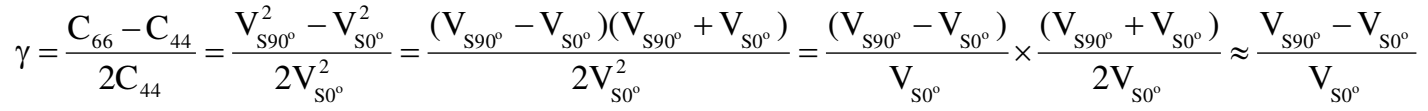

$$
\begin{aligned}
& \delta=\frac{\left(\mathrm{C}_{13}+\mathrm{C}_{44}\right)^{2}-\left(\mathrm{C}_{33}-\mathrm{C}_{44}\right)^{2}}{2 \mathrm{C}_{33}\left(\mathrm{C}_{33}-\mathrm{C}_{44}\right)}=\frac{\left(\mathrm{C}_{13} / \rho+\mathrm{V}_{\mathrm{S}^{\circ}}^{2}\right)^{2}-\left(\mathrm{V}_{\mathrm{P}^{\circ}}^{2}-\mathrm{V}_{\mathrm{S}^{\circ}}^{2}\right)^{2}}{2 \mathrm{~V}_{\mathrm{P}^{\circ}}^{2}\left(\mathrm{~V}_{\mathrm{P}^{\circ}}^{2}-\mathrm{V}_{\mathrm{S}^{\circ}}^{2}\right)}
\end{aligned}
$$

Where $\varepsilon=$ anisotropy parameter that is the percentage change of $\mathrm{V}_{\mathrm{P} 90^{\circ}}$ with respect to $\mathrm{V}_{\mathrm{P0}^{\circ}}$,

$$
\gamma=\text { anisotropy parameter that is the percentage change of } \mathrm{V}_{\mathrm{S}^{\circ} 0^{\circ}} \text { with respect to } \mathrm{V}_{\mathrm{S}^{\circ}} \text {, }
$$


$\delta=$ anisotropy parameter, can be viewed as a measure of the anellipticity of the P wave curve (Cholach and Schmitt 2006).

The relation between $V_{p(\theta)}$ and $\theta$ angle has been given by Thomsen (1986) as follows:

$\mathrm{V}_{\mathrm{P}(\theta)}=\mathrm{V}_{\mathrm{P} 0}{ }^{\mathrm{O}}\left(1+\delta \sin ^{2} \theta \cos ^{2} \theta+\varepsilon \sin ^{4} \theta\right)$

To determine $\delta$ value or $\mathrm{V}_{\mathrm{P}(\theta)}$ as a function of $\theta$ angle, four parameters of $\mathrm{V}_{\mathrm{P} 0}{ }^{\circ}, \mathrm{V}_{\mathrm{P} 90^{\circ}}, \mathrm{V}_{\mathrm{S} 0}{ }^{\circ}$ and $\mathrm{V}_{\mathrm{P} 60}{ }^{\circ}$ are necessary to be measured. $\delta$ can also be calculated in the case of weak anisotropy by measurements the three parameters of $\mathrm{V}_{\mathrm{P} 0}{ }^{\circ}$, $\mathrm{V}_{\mathrm{P} 90^{\circ}}$ and $\mathrm{V}_{\mathrm{S} 45^{\circ}}$ as follow (Thomsen 1986):

$\delta=4\left[\frac{\mathrm{V}_{{\mathrm{P} 45^{\circ}}^{\circ}}}{\mathrm{V}_{\mathrm{P}^{\circ}}}-1\right]-\left[\frac{\mathrm{V}_{{\mathrm{P} 90^{\circ}}^{\circ}}}{\mathrm{V}_{\mathrm{P}^{\circ}}}-1\right]$

\section{Comparison between effect of textural and jointed anisotropy on P-wave velocity}

P-wave velocity anisotropy can be affected by orientations of rock forming crystals and their textural arrangements and parameters such as rock fractures, cracks and joints as dominant weakness planes. P-wave velocity anisotropy of quartz-mica schist is compared with the P-wave velocity anisotropy of jointed homogeneous limestone specimens to clarify the difference between effect of textural and jointed anisotropy of rocks on the P-wave velocity. Mica-rich rocks (shales, slates, schists) are often characterized by a strong seismic anisotropy (Cardenes et al. 2021). Quartzmica schist as a common type of metamorphic rock has a widespread distribution in the world, including Scottish Highlands, Norway, Sweden, China, India, Bohemia, Saxony, Brittany, the Alps, Himalayas, and many parts of North America. The geotechnical challenges associated with quartz-mica schist has been reported in many rock engineering projects (Zhang et al. 2011).

Five groups of cylindrical spesimens having $5.4 \mathrm{~cm}$ diameter (NX size) were cored at different foliation orientation angles $(\theta)$ of $0^{\circ}, 30^{\circ}, 45^{\circ}, 60^{\circ}$ and $90^{\circ}$ by the core drilling machine (Fig. 1) from the quartz-mica schist blocks of Angouran mine. Angouran mine is located in $135 \mathrm{~km}$ west of Zanjan city, Northwest of Iran. For preparation of each specimen, the coring direction with respect to the foliation plane of the rock block was designed to obtaine a cylindrical specimen having a particular foliation angle. The core specimens were cut at both ends by the diamond core cutting machine (Fig. 2) to make prefect contacts for the ultrasonic transducers. The cylinderical specimens having length to diameter ratio of 2.0 to 2.5 were prepared according to the ISRM standard (International Society of Rock Mechanics 1978). Petrographic studies under polorized microscope show that the samples have well foliated schistosity that consists quartz micaschist more than 50 percent quartz minerals, and other minerals including biotite, cordierite, kyanite and chlorite (Fig. 3). 


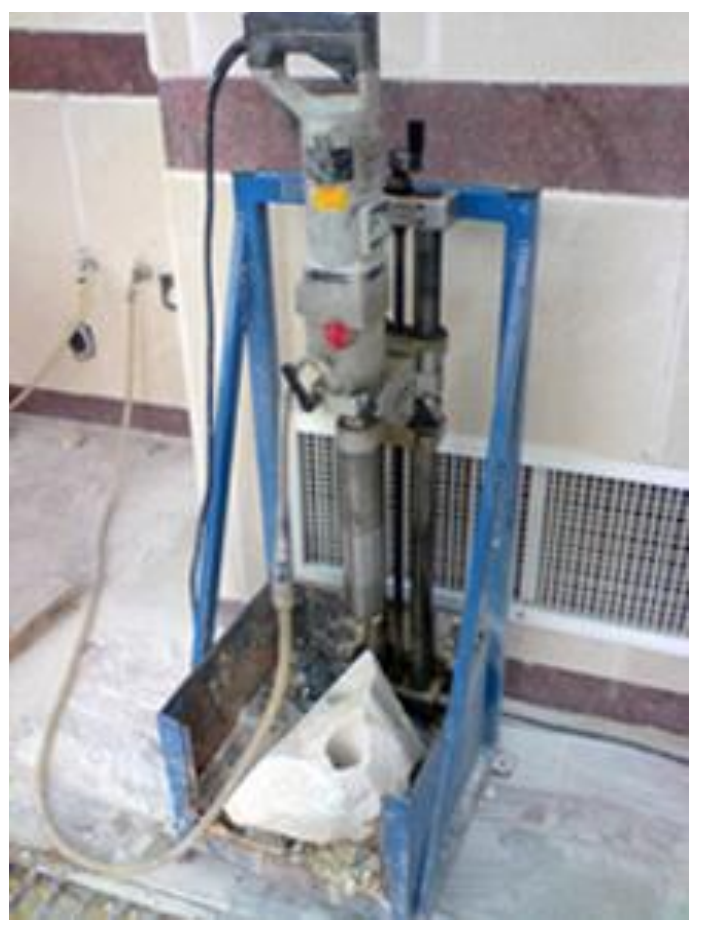

Fig. 1 Core drilling machine

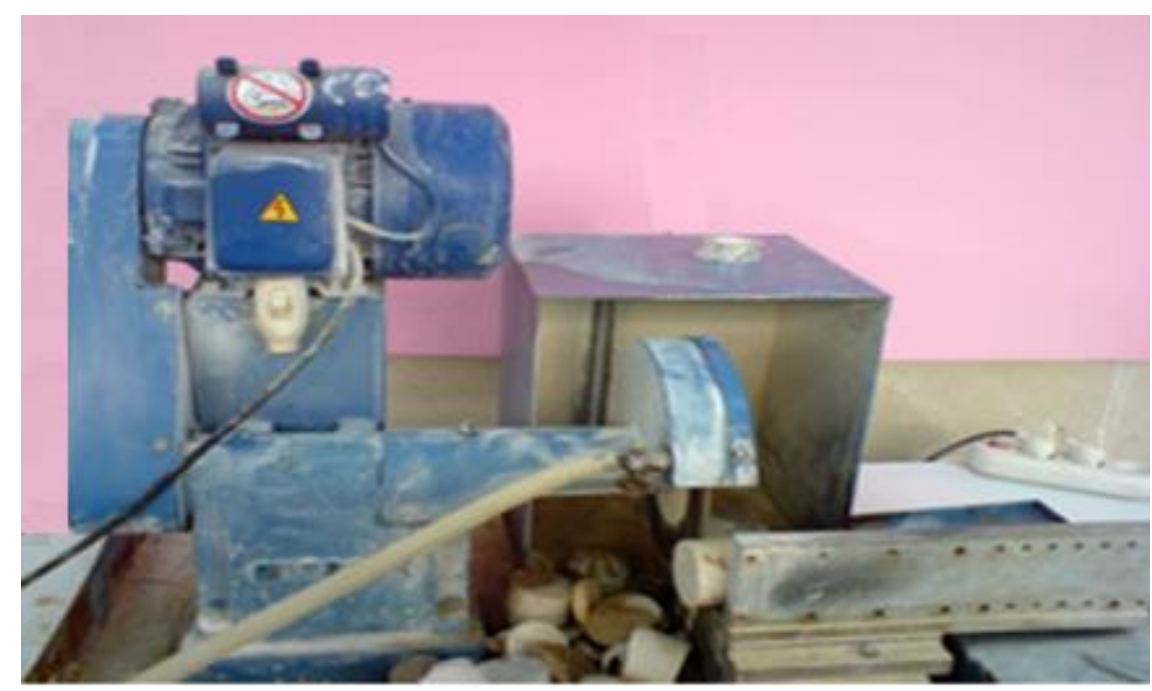

Fig. 2 Core cutting machine 
With the same way cylindrical spesimens having $5.4 \mathrm{~cm}$ diameter were cored from homogeneus limestone blocks of Naghadeh imestone mine. Naqadeh is located in $23 \mathrm{~km}$ South of Lake Urmia in West Azerbaijan Province of Iran. Five groups of cylindrical limestone rock specimens having joint orientation ( $\theta$ angle) of $0,30,45,60$ and 90 degrees were also prepared by the core cutting machine (Figs. 2 and 4). The orientaion angles of microscopic pictures of the well foliated schistosity in quartz-mica schist has been compared with orientation angle of jointed limestone specimens in Fig. 5. $V_{P}$ of 10 groups of cylindrical quartz-mica schist and jointed limestone specimens having different orientaion angles $(\theta)$ of $0^{\circ}, 30^{\circ}, 45^{\circ}, 60^{\circ}$ and $90^{\circ}$ were measured acording ISRM stantard (ISRM 1978) (Fig. 6). The $\mathrm{V}_{\mathrm{P}}$ results of two different textural and jointed anisotropies are given in Table 1 . The effect of $\theta$ angle on $V_{P}$ of foliated schistosity in quartz-mica schist specimens was compared with the effect $\theta$ angle on the $V_{P}$ of jointed homogeneous limestone specimens. The results showed that the $V_{P}$ anisotropy of rock texture in quartz-mica schist is stronger than the $V_{P}$ anisotropy of jointed rock (Figs. 7 and 8). That is because all body of quartz-mica schist specimens have textural anisotropy hence $V_{P}$ anisotropy behaviour.

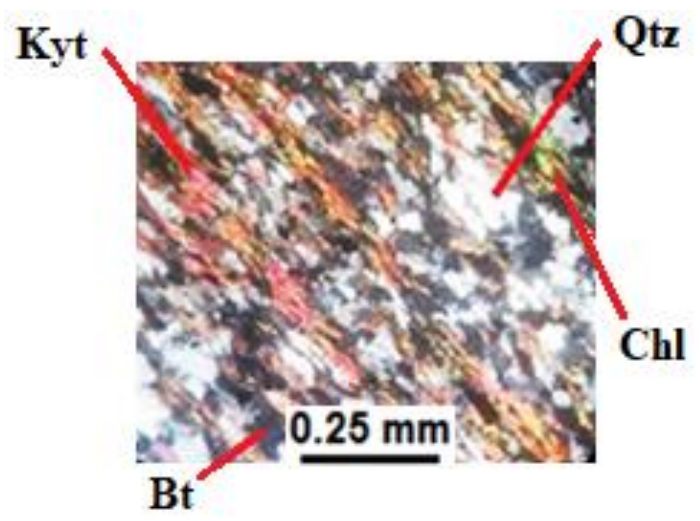

Fig. 3 Microscopic XPL picture of the well foliated schistosity in a specimen containg Biotite (Bt), Chlorite (Chl), Quartz (Qtz) and Kyanite (Kyt). 


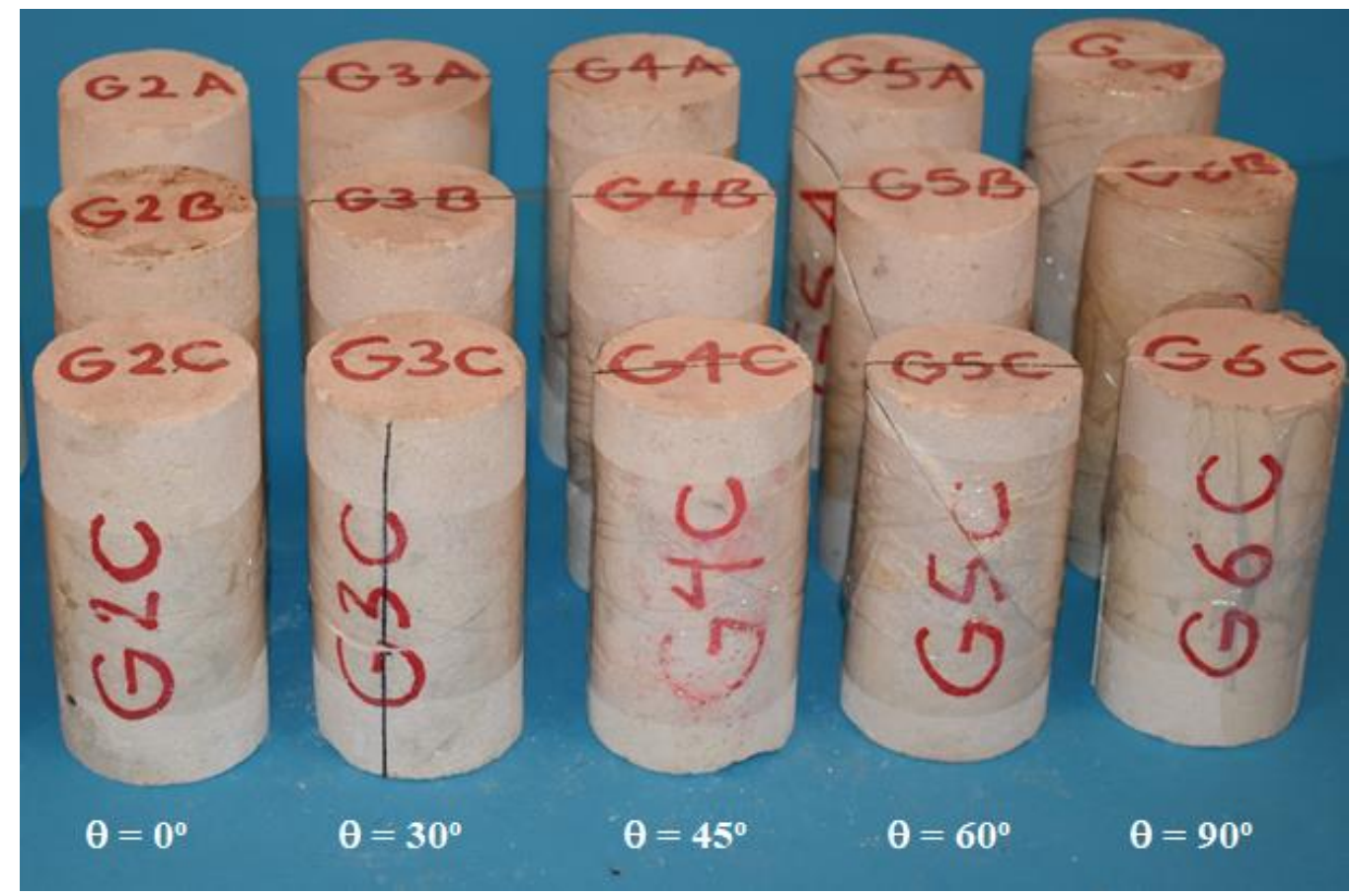

Fig. 4 The prepared jointed Naqadeh limestone specimens with orientation angles $(\theta)$ 0, 30, 45, 60 and 90 degrees

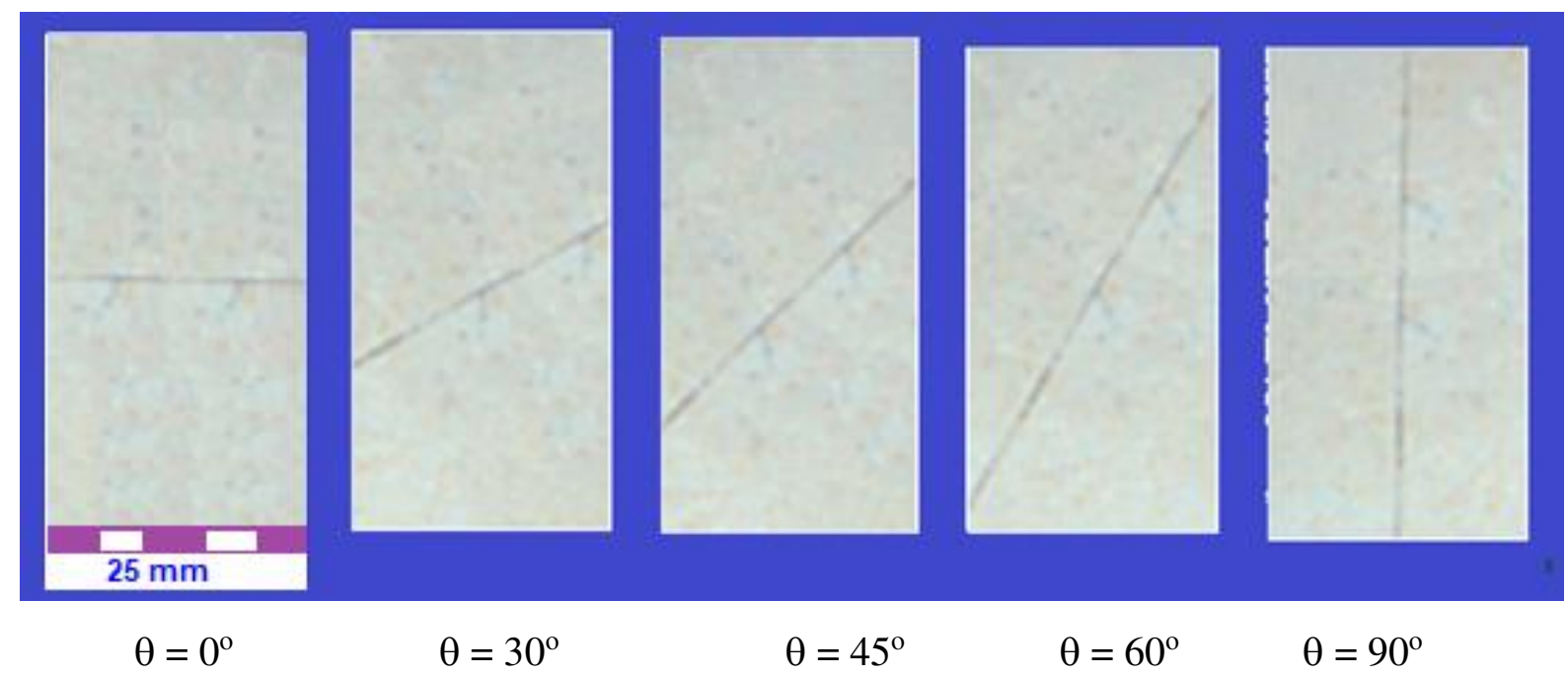

A) Jointed Naqadeh limestone 

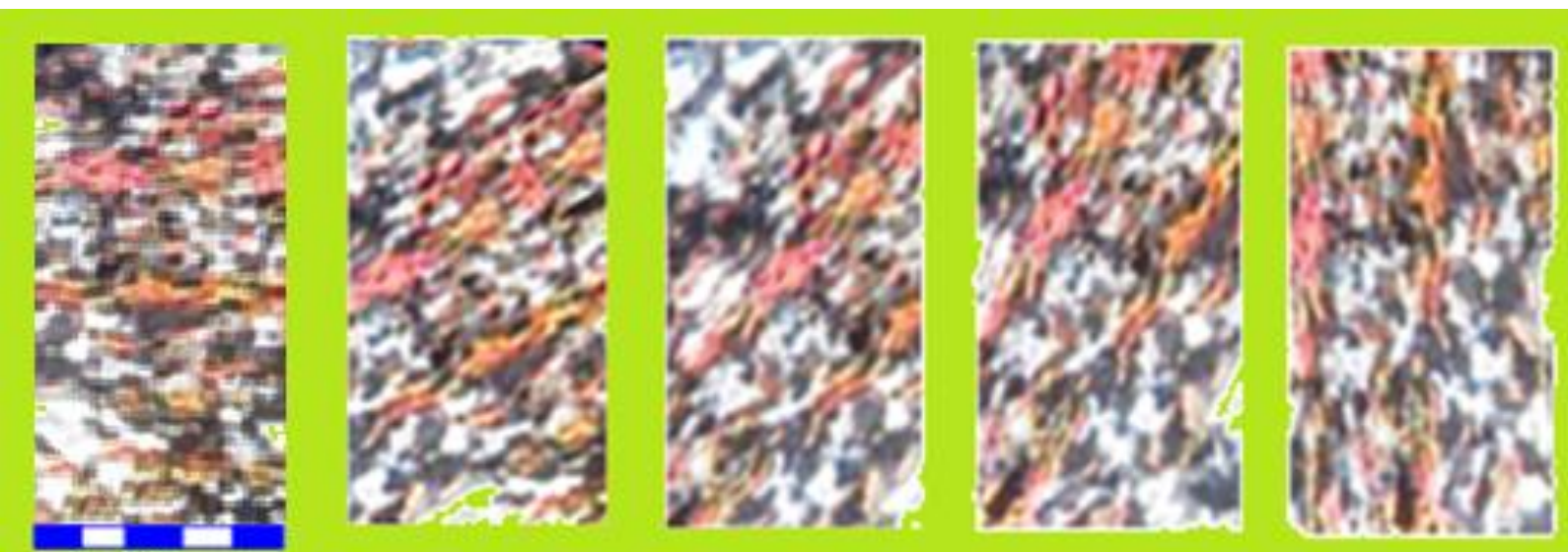

$0.30 \mathrm{~mm}$

$$
\theta=0^{\circ} \quad \theta=30^{\circ}
$$

$$
\theta=45^{\circ}
$$$$
\theta=60^{\circ}
$$$$
\theta=90^{\circ}
$$

B) Angouran quartz-mica schist

Fig. 5 The of microscopic pictures of orientaion angles in well foliated schistosity in Angouran quartz-mica schist and jointed Naqadeh limestone specimens 


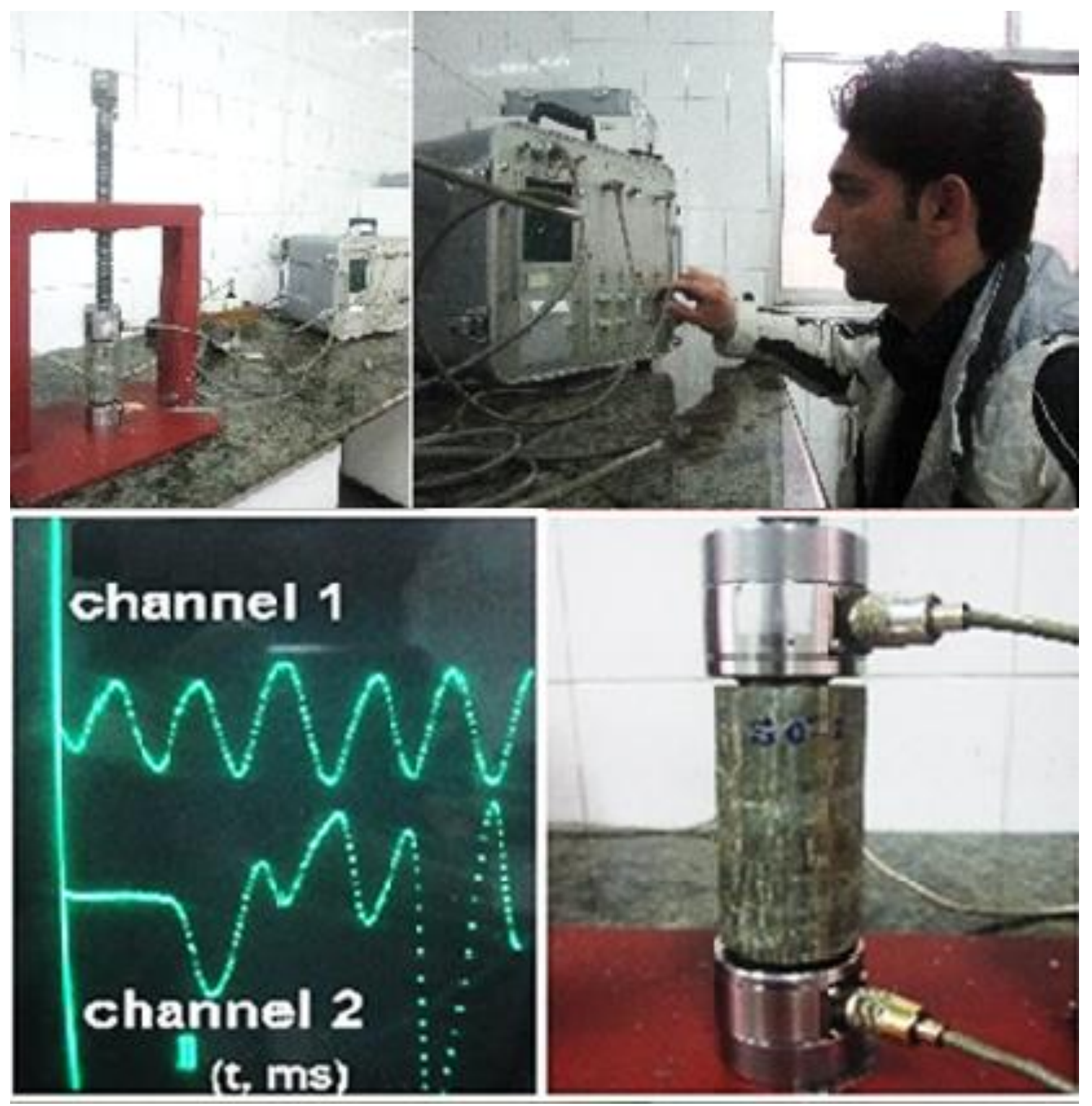

Fig. 6 Testingt equipment of ultrasonic wave velocity system 
Table 1 Measured P-wave velocity at diferent directions with foliated schistosity in Angouran quartz-mica schist (QMS) and jointed Naqadeh limestone specimens having $5.4 \mathrm{~cm}$ diameter

\begin{tabular}{|c|c|c|c|c|c|c|c|c|c|c|c|}
\hline \multicolumn{6}{|c|}{$\begin{array}{l}\text { P-wave velocity of Angouran quartz-mica schist } \\
\text { specimens with different orientation angles of schistosity } \\
(\theta) \text { from } 0 \text { to } 90 \text { degrees }\end{array}$} & \multicolumn{6}{|c|}{$\begin{array}{l}\text { P-wave velocity of jointed Naqadeh jointed limestone } \\
\text { specimens with different orientation angles }(\theta) \text { from } 0 \text { to } \\
90 \text { degrees }\end{array}$} \\
\hline $\begin{array}{c}\text { Symbolic } \\
\text { direction } \\
\text { of foliated } \\
\text { schistosity } \\
\text { in QMS } \\
\text { specimens }\end{array}$ & $\begin{array}{c}\theta \\
\text { (Degree) }\end{array}$ & $\begin{array}{c}\text { Specimen } \\
\text { No. }\end{array}$ & $\begin{array}{c}\mathrm{V}_{\mathrm{P}} \\
(\mathrm{m} / \mathrm{s})\end{array}$ & $\begin{array}{c}V_{\text {P-average }} \\
(\mathrm{m} / \mathrm{s})\end{array}$ & $\begin{array}{c}\text { Standard } \\
\text { deviation } \\
(\mathrm{m} / \mathrm{s})\end{array}$ & $\begin{array}{l}\text { Symbolic } \\
\text { direction } \\
\text { of joint in } \\
\text { limeston } \\
\text { specimens }\end{array}$ & $\begin{array}{c}\theta \\
\text { (Degree) }\end{array}$ & $\begin{array}{c}\text { Specimen } \\
\text { No. }\end{array}$ & $\begin{array}{c}\mathrm{V}_{\mathrm{P}} \\
(\mathrm{m} / \mathrm{s})\end{array}$ & $\begin{array}{c}V_{\text {P-average }} \\
(\mathrm{m} / \mathrm{s})\end{array}$ & $\begin{array}{c}\text { Standard } \\
\text { deviation } \\
(\mathrm{m} / \mathrm{s})\end{array}$ \\
\hline \multirow{3}{*}{ 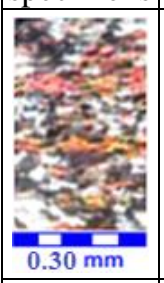 } & \multirow{3}{*}{0} & QMS0-1 & 3618 & \multirow{3}{*}{3737} & \multirow{3}{*}{232} & & \multirow{3}{*}{0} & Lim0-1 & 3316 & \multirow{3}{*}{3336} & \multirow{3}{*}{177} \\
\hline & & QMS0-2 & 3589 & & & & & Lim0-2 & 3522 & & \\
\hline & & QMS0-3 & 4005 & & & $25 \mathrm{~mm}$ & & Lim0-3 & 3171 & & \\
\hline \multirow{3}{*}{ 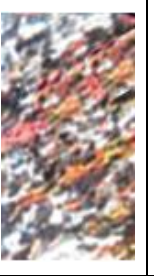 } & \multirow{3}{*}{30} & QMS30-1 & 3763 & \multirow{3}{*}{3790} & \multirow{3}{*}{137} & & \multirow{3}{*}{30} & Lim30-1 & 3561 & \multirow{3}{*}{3328} & \multirow{3}{*}{214} \\
\hline & & QMS30-2 & 3668 & & & & & $\operatorname{Lim} 30-2$ & 3283 & & \\
\hline & & QMS30-3 & 3938 & & & & & Lim30-3 & 3140 & & \\
\hline \multirow{3}{*}{ 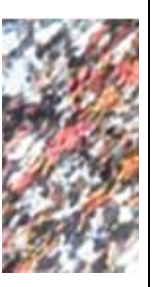 } & \multirow{3}{*}{45} & QMS45-1 & 3941 & \multirow{3}{*}{3887} & \multirow{3}{*}{464} & & \multirow{3}{*}{45} & Lim45-1 & 3772 & \multirow{3}{*}{3505} & \multirow{3}{*}{252} \\
\hline & & QMS45-2 & 3399 & & & & & Lim45-2 & 3470 & & \\
\hline & & QMS45-3 & 4322 & & & & & Lim45-3 & 3272 & & \\
\hline \multirow{3}{*}{ 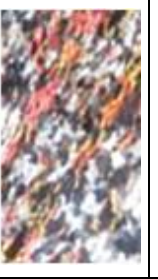 } & \multirow{3}{*}{60} & QMS60-1 & 5157 & \multirow{3}{*}{4974} & \multirow{3}{*}{163} & & \multirow{3}{*}{60} & Lim60-1 & 3993 & \multirow{3}{*}{3699} & \multirow{3}{*}{316} \\
\hline & & QMS60-2 & 4918 & & & & & Lim60-2 & 3737 & & \\
\hline & & QMS60-3 & 4846 & & & & & Lim60-3 & 3365 & & \\
\hline \multirow{3}{*}{ 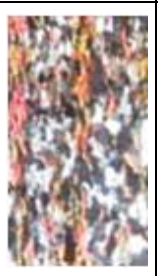 } & \multirow{3}{*}{90} & QMS90-1 & 5430 & \multirow{3}{*}{5639} & \multirow{3}{*}{182} & & \multirow{3}{*}{90} & Lim90-1 & 4246 & & \\
\hline & & QMS90-2 & 5730 & & & & & Lim90-2 & 3886 & 3963 & 254 \\
\hline & & QMS90-3 & 5758 & & & & & Lim90-3 & 3757 & & \\
\hline
\end{tabular}




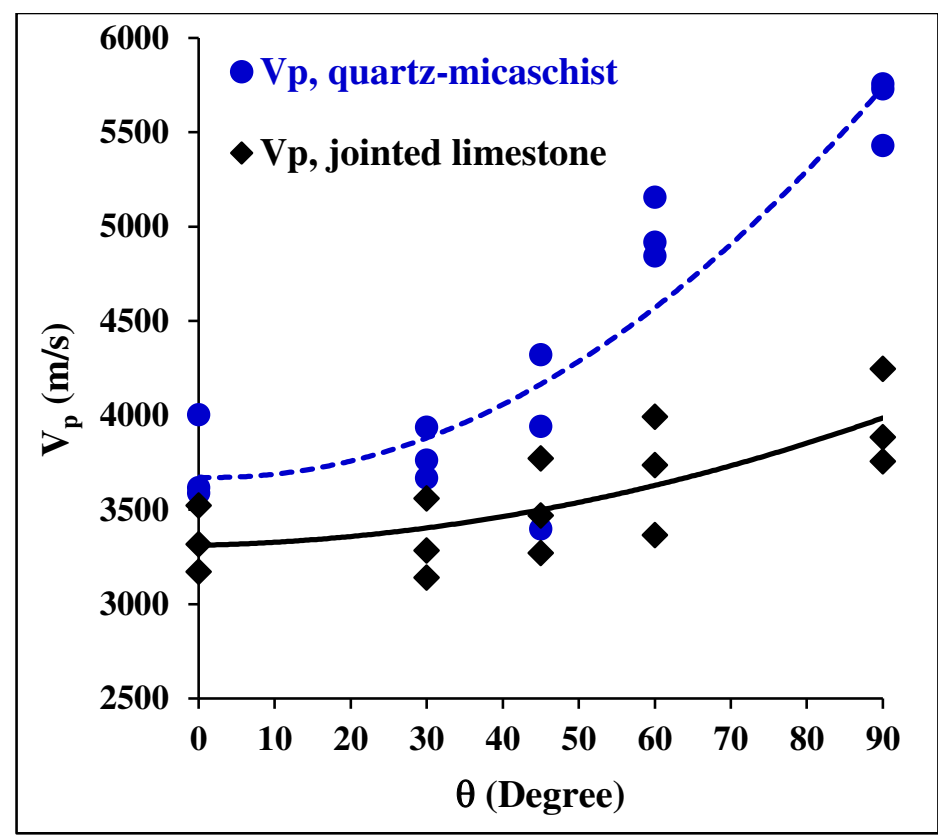

Fig. 7 Comparison between P-wave velocity anisotropy in quartz-mica schist and jointed limestone specimens

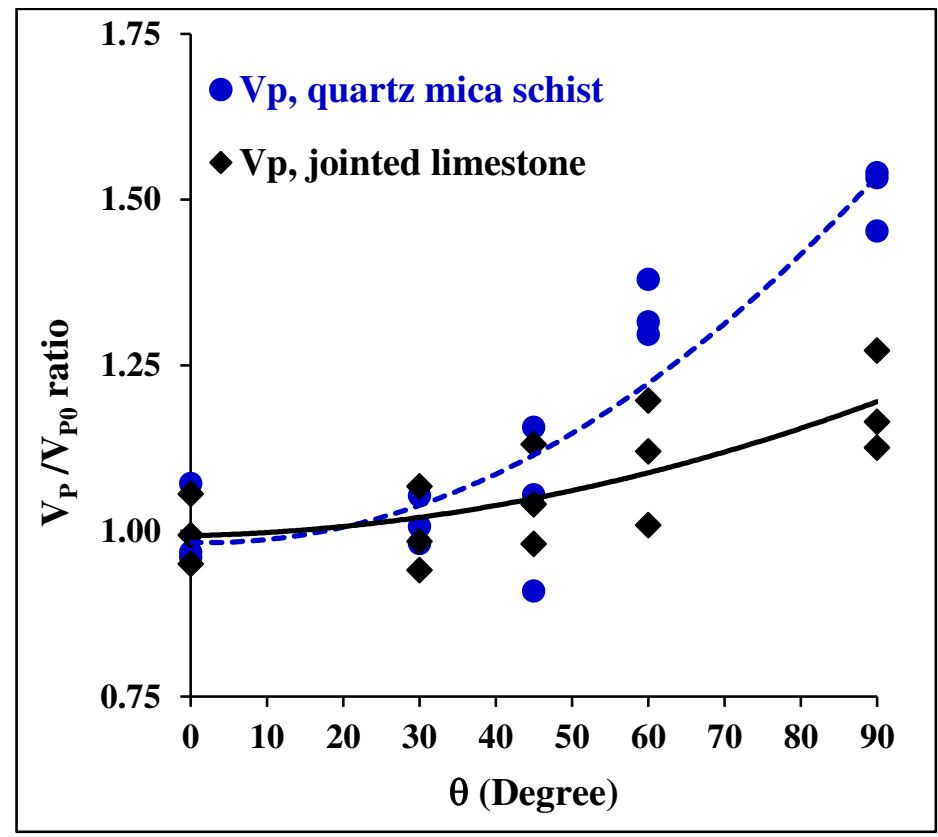

Fig. 8 Comparison between effect $\theta$ angle on $\mathrm{V}_{\mathrm{P}} / \mathrm{V}_{\mathrm{P} 0}$ ratio in quartz-mica schist and jointed limestone specimens 


\section{Analysis of the relation between $P$-wave velocity and $\theta$ angle for different anisotropy degrees}

Many rocks are anisotropic and degree of anisotropy varies from one to another. Despite several investigations have been carried out on $\mathrm{V}_{\mathrm{P}}$ anisotropy but there is not a unique comprehensive relation to represent the influence of different degrees of anisotropy on the $V_{P}$ for different rocks. The relation between $V_{P}$ and $\theta$ angle was analyzed for a wide range of degree of anisotropy using the results of Angouran quartz-mica schist of this study and other eight groups of results including: Golgohar mica schist, amphibole schist, mica-quart schist (Hajiheidari et al. 2016), Marcellus shale (Jin et al. 2018), Withby shale WUK47B, WUK70, WUK2 under the same relatively small axial stress (Zhubayev et al. 2016) and Veroia-Polymylos gneiss (Saroglou et al. 2004). The $\varepsilon$ value varied in a wide range from 0.324 to 1.63 as the maximum value of $\varepsilon$ is 3.6 times of its minimum value. Several relations were applied to find a better function fit to the nine different groups of results. At the end the following exponential relation was achieved as a best fit to the results:

$$
\mathrm{V}_{(\mathrm{P} \theta)}=\mathrm{V}_{\mathrm{P}^{\circ}} \mathrm{e}^{(\mathrm{K} \theta)}
$$

Where,

$$
\begin{aligned}
& \mathrm{V}_{(\mathrm{P} \theta)}=\mathrm{P} \text {-wave velocity at } \theta \text { angle, } \\
& \mathrm{K}=\text { a constant coefficient for different types of anisotropies. }
\end{aligned}
$$

The relation between $V_{P}$ and $\theta$ angle for nine groups of results with the acceptable correlations are shown in Fig. 9. For better comparison between nine groups of results having different $\varepsilon$ values, the dimensionless relations between ratio of $\mathrm{V}_{\mathrm{P}} / \mathrm{V}_{\mathrm{P} 0}$ and $\theta$ angle are also shown in Fig. 10. The values of $\mathrm{V}_{\mathrm{P} 0}, \mathrm{~V}_{\mathrm{P} 90}, \varepsilon$ and $\mathrm{K}$ and correlation of determination $\left(\mathrm{R}^{2}\right)$ of the relations are given in Table 2. The parameter $\mathrm{K}$ varies from one rock (group of results) to another. But the relation between $\mathrm{K}$ and $\varepsilon$ was obtained with a good correlation $\left(\mathrm{R}^{2}=0.959\right)$ as follows (Fig 11):

$$
\mathrm{K}=0.0057 \varepsilon+0.0015
$$

Using Eqs. 23 and 24, the relation between $\mathrm{V}_{\mathrm{P} 0}$ and $\theta$ angle for all groups of results is as follows:

$$
\mathrm{V}_{(\mathrm{P} \theta)}=\mathrm{V}_{\mathrm{P}^{\circ}} \mathrm{e}^{(0.0057 \varepsilon+0.0015) \theta}
$$




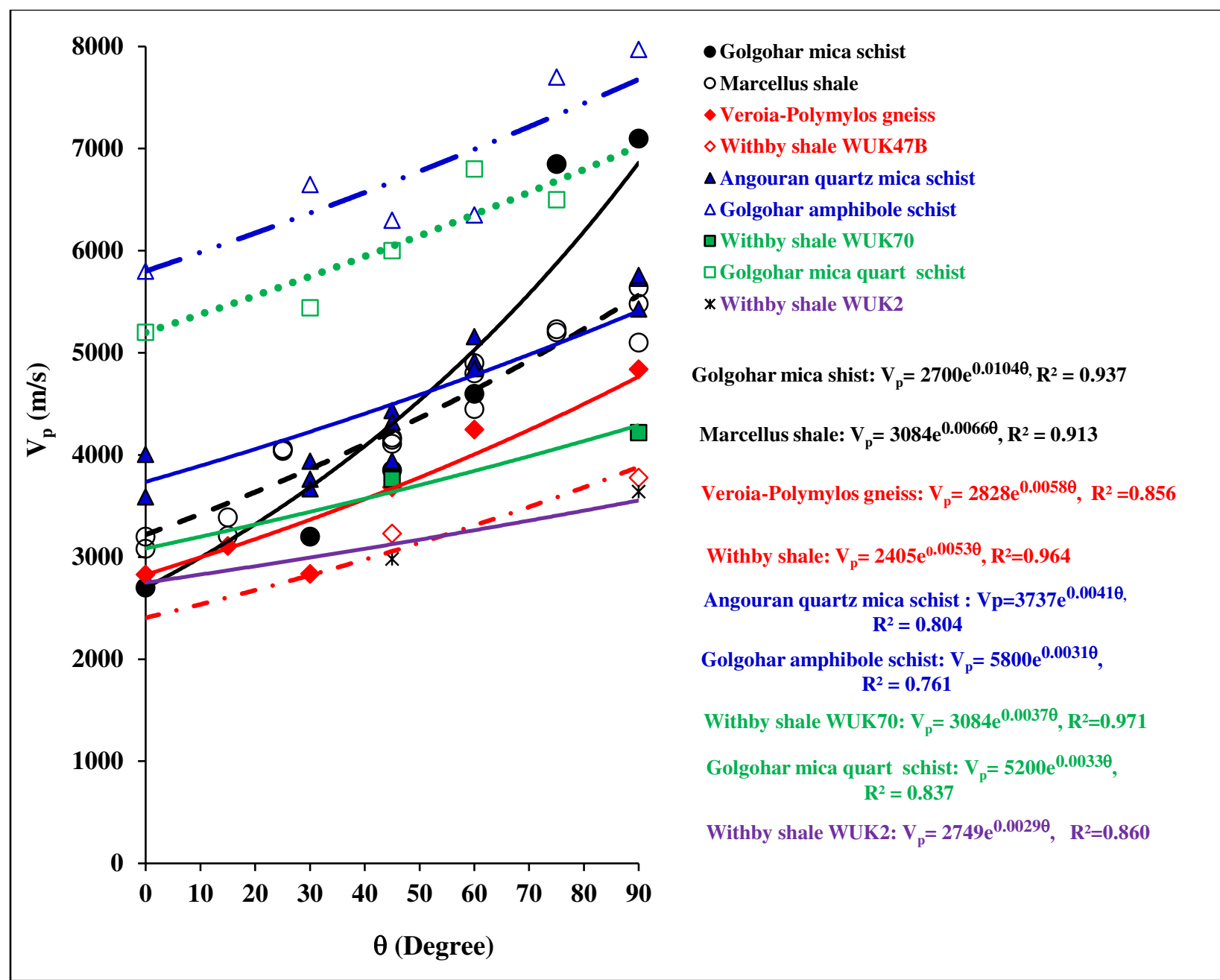

Fig. 9 The best fuction fit to the relation between $V_{P}$ and $\theta$ angle for different types of rocks 


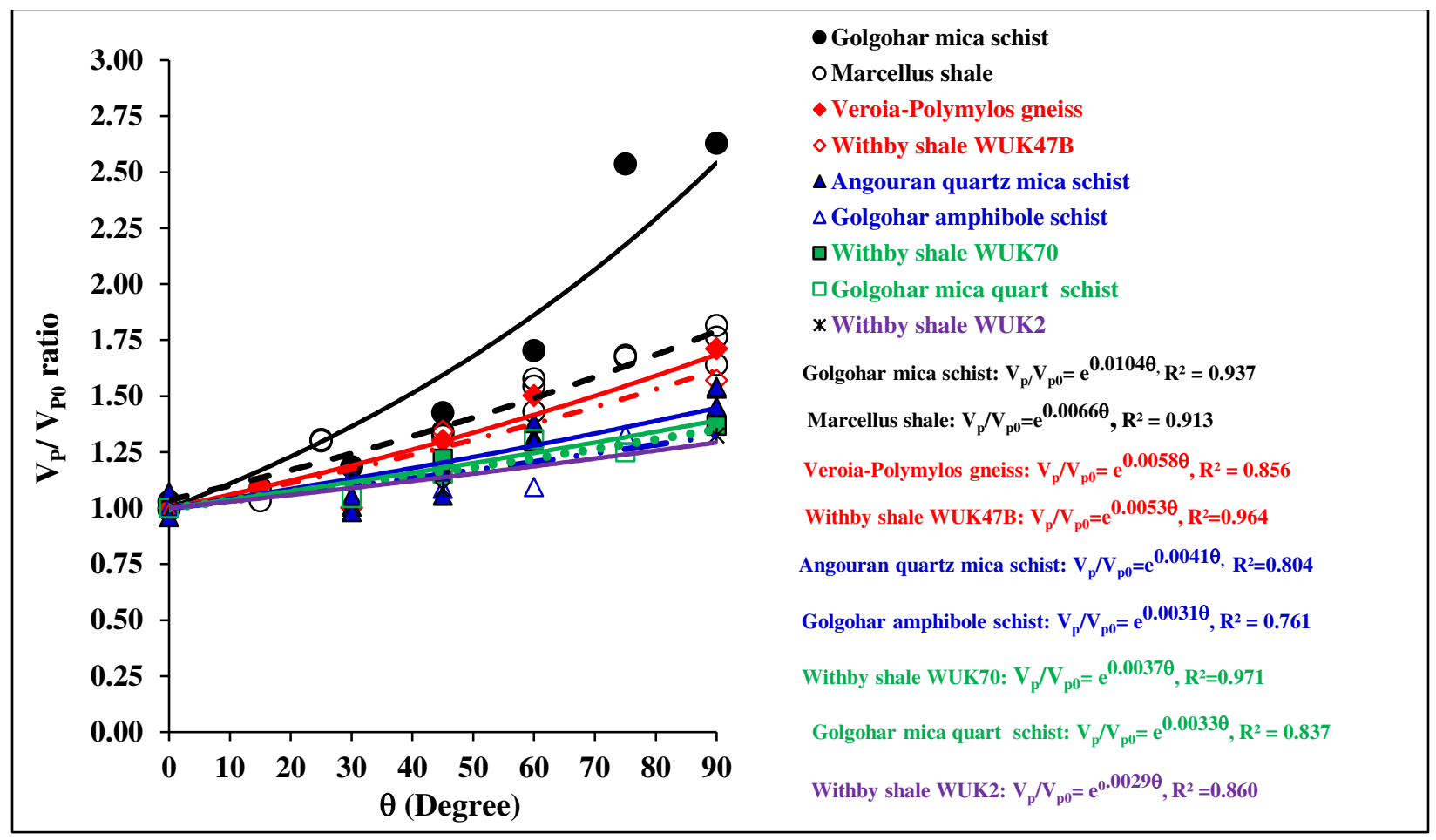

Fig. 10 Relation between $\mathrm{V}_{\mathrm{P}} / \mathrm{V}_{\mathrm{P} 0} \mathrm{o}$ ratio and $\theta$ angle for different types of rocks

Table $2 \mathrm{~V}_{\mathrm{P} 0}, \mathrm{~V}_{\mathrm{P} 90}, \varepsilon$, coefficient $\mathrm{K}$ of the obtained relations for 9 groups of results

\begin{tabular}{|c|c|c|c|c|c|c|}
\hline No. & Type of rock and reference & $\begin{array}{l}\mathrm{V}_{\mathbf{P 0}} \\
(\mathrm{m} / \mathrm{s})\end{array}$ & $\begin{array}{l}\mathrm{V}_{\mathrm{P} 90} \mathrm{o} \\
(\mathrm{m} / \mathrm{s})\end{array}$ & $\varepsilon$ & $\mathrm{K}$ & $\mathrm{R}^{2}$ \\
\hline 1 & Golgohar Mica schist (Hajiheidari et al., 2016) & 2700 & 7100 & 1.630 & 0.0104 & 0.937 \\
\hline 2 & Marcellus shale (Jin et al., 2018) & 3108 & 5407 & 0.740 & 0.0066 & 0.913 \\
\hline 3 & Veroia-Polymylos gneiss (Saroglou et al., 2004) & 2828 & 4839 & 0.711 & 0.0058 & 0.856 \\
\hline 4 & Withby shale WUK47B (Zhubayev et al., 2016) & 2405 & 3777 & 0.570 & 0.0053 & 0.964 \\
\hline 5 & Angouran quartz-mica schist (This study) & 3737 & 5639 & 0.509 & 0.0041 & 0.804 \\
\hline 6 & Golgohar amphibole schist (Hajiheidari et al., 2016) & 5800 & 7970 & 0.374 & 0.0031 & 0.762 \\
\hline 7 & Withby shale WUK70 (Zhubayev et al. 2016) & 3084 & 4218 & 0.368 & 0.0037 & 0.971 \\
\hline 8 & $\begin{array}{l}\text { Golgohar mica quart schist (Hajiheidari et al., } \\
\text { 2016) }\end{array}$ & 5200 & 6800 & 0.308 & 0.0033 & 0.836 \\
\hline 9 & Withby shale WUK2 (Zhubayev et al., 2016) & 2749 & 3640 & 0.324 & 0.0029 & 0.860 \\
\hline
\end{tabular}




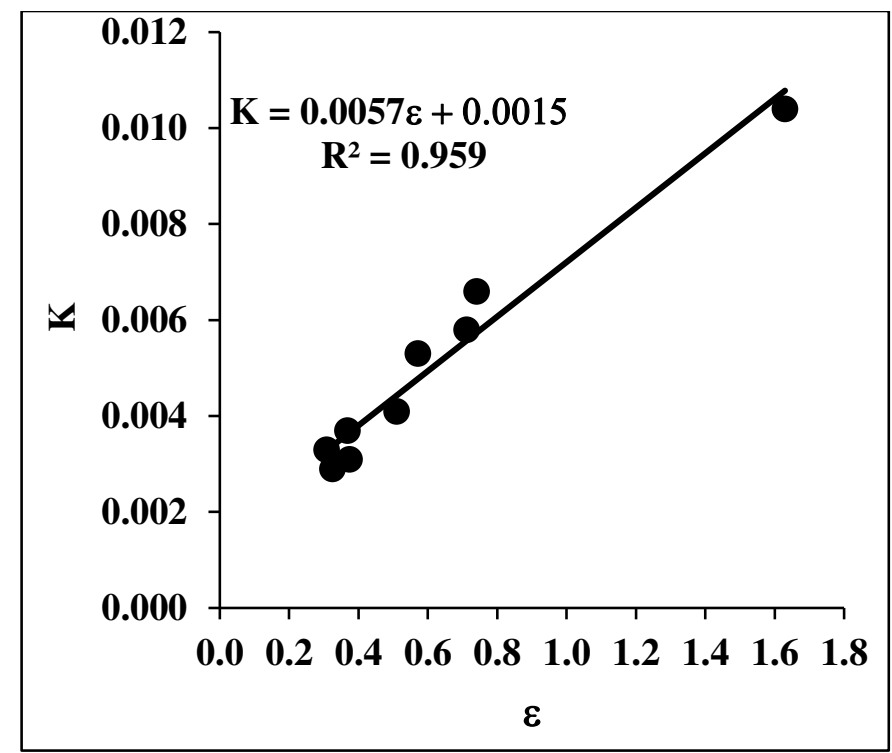

Fig. 11 Relation between coefficients $\mathrm{K}$ and $\varepsilon$ for different types of rocks

In Eq. 16, the $V_{\mathrm{P} 0}$ and $\varepsilon$ vary from one group another. $V_{\mathrm{P}}$ of nine groups was predicted by Eq. 16. The predicted $V_{\mathrm{P}}$ was compared with the measured $\mathrm{V}_{\mathrm{P}}$ in Fig. 12. The correlation of determination $\left(\mathrm{R}^{2}\right)$, root mean square error (RMSE) and coefficient of variation $(\mathrm{CV})$ of the predicted $V_{P}$ with measured $V_{P}$ were determined. The coefficient of variation (CV) known as relative RMSE. It is often expressed as a percentage, and is defined as the ratio of the RMSE to the mean. There is a good correlation between predicted $V_{P}$ and measured $V_{P}$ for all groups of results with $R^{2}=0.937$, RMSE $=320 \mathrm{~m} / \mathrm{s}$ and $\mathrm{CV}=7.0 \%$. The obtained new empirical relation can represent the $\mathrm{V}_{P}$ as a function of $\theta$ angle for different types of rock. In addition, the relation between $V_{P}$ and $\theta$ angle can simply be determined by two parameters of $\mathrm{V}_{\mathrm{P} 0}$ and $\mathrm{V}_{\mathrm{P} 90}$ or $\left.\left.\left[\varepsilon=\mathrm{V}_{\mathrm{P} 90}-\mathrm{V}_{\mathrm{P} 0}\right) / \mathrm{V}_{\mathrm{P} 0}\right)\right]$.

The developed relation was validated using four groups of $\mathrm{V}_{\mathrm{P}}$ anisotropy for gneiss, phyllite, schist and slate (Tsidzi 1997). The predicted $V_{P}$ using developed relation in this study has significant correlation $\left(R^{2}=0.943\right.$, $R M S E=284$ $\mathrm{m} / \mathrm{s}$ and $\mathrm{CV}=5.4 \%$ ) with the results (Fig. 13). A new $\mathrm{V}_{\mathrm{P}}$ anisotropy classification was also developed by the obtained empirical relation using a wide range of $\varepsilon$ values (Fig. 11). Five classes of P-wave velocity anisotropy were defined using different ranges of $\varepsilon$ values including: very weak anisotropy $(\varepsilon<0.1)$, weak anisotropy $(0.1 \leq \varepsilon<0.3)$, medium anisotropy $(0.3 \leq \varepsilon<0.7)$, strong anisotropy $(0.7 \leq \varepsilon<0.1 .3)$ and very strong anisotropy $(1.3 \leq \varepsilon)$ values (Fig. 14). 


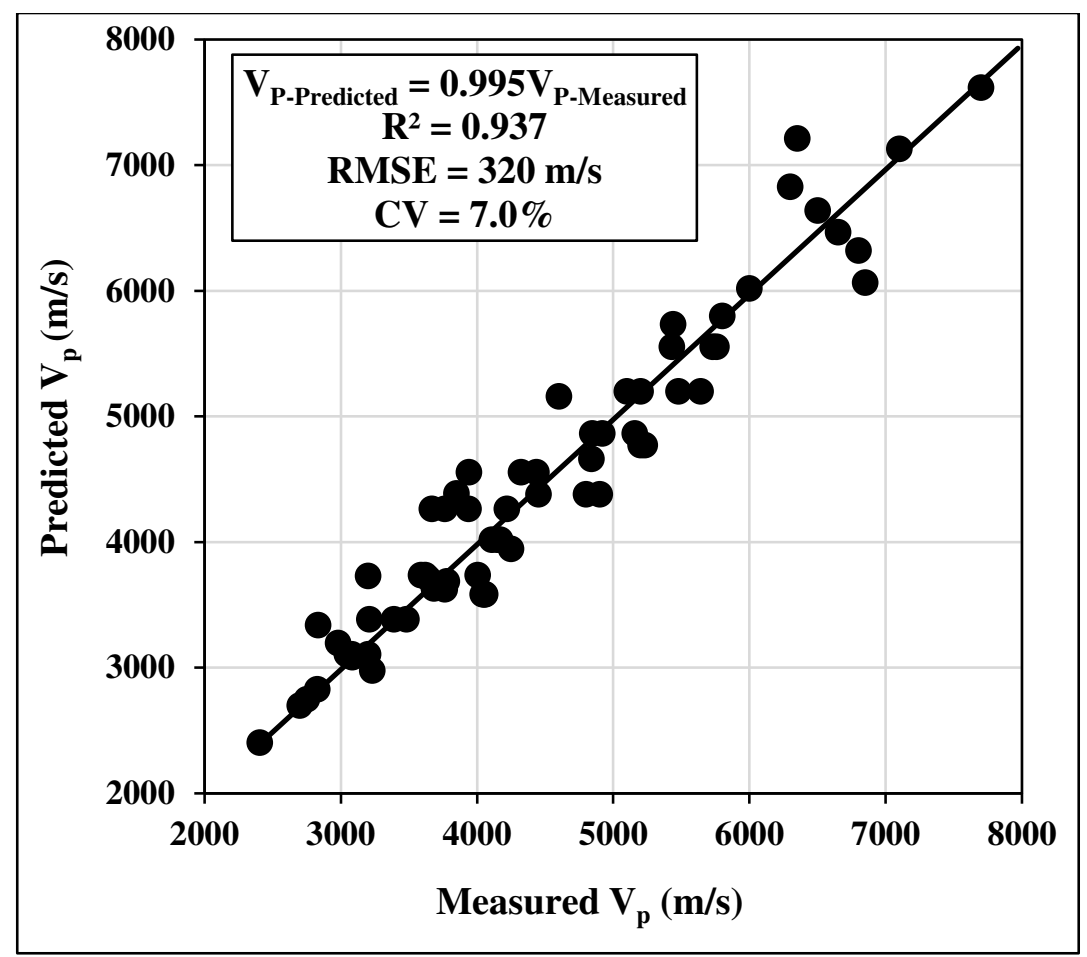

Fig. 12 Comparison between predicted $V_{P}$ and measured $V_{P}$ for different groups of results

Table 3 Measured $V_{P}$ of gneiss, phyllite, schist and slate with varying $\theta$ angle (Tsidzi, 1997) and predicted $V_{P}$ using developed relation in this study

\begin{tabular}{|c|c|c|c|c|}
\hline Rock type & $\theta$ & Measured $V_{p}$ & $\varepsilon$ & Predicted $V_{P}$ \\
\hline \multirow{3}{*}{ Gneiss } & 0 & 3956 & \multirow{3}{*}{0.290} & 3956 \\
\hline & 45 & 4211 & & 4559 \\
\hline & 90 & 5102 & & 5254 \\
\hline \multirow{3}{*}{ Phyllite } & 0 & $\begin{array}{l}5090 \\
\end{array}$ & \multirow{3}{*}{0.181} & $\begin{array}{l}5090 \\
\end{array}$ \\
\hline & 45 & 5130 & & 5704 \\
\hline & 90 & 6010 & & 6393 \\
\hline \multirow{3}{*}{ Schist } & 0 & 5151 & \multirow{3}{*}{0.289} & 5151 \\
\hline & 45 & 5802 & & 5935 \\
\hline & 90 & 6641 & & 6838 \\
\hline \multirow{3}{*}{ Slate } & 0 & 4893 & \multirow{3}{*}{0.208} & 4893 \\
\hline & 45 & 5074 & & 5522 \\
\hline & 90 & 5913 & & 6231 \\
\hline
\end{tabular}




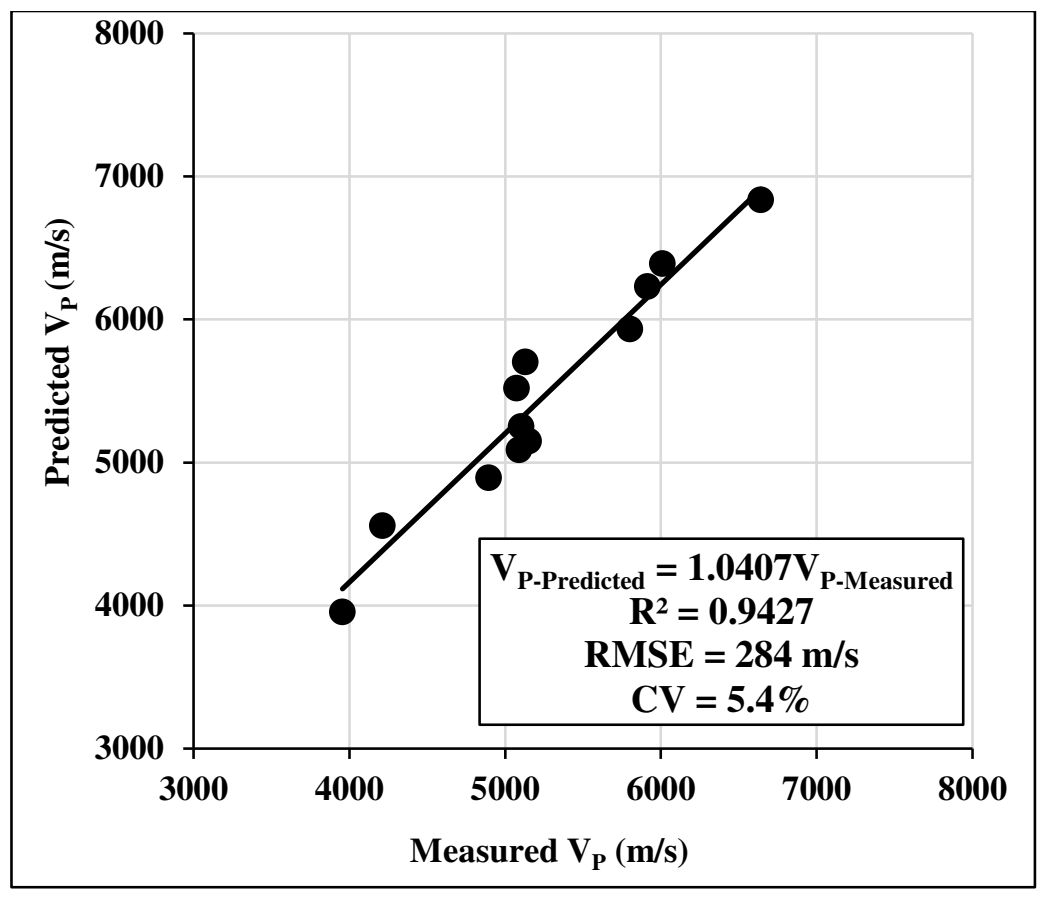

Fig. 13 Validation of predicted $V_{P}$ by the developed relation and the meaured $V_{P}$ of gneiss, phyllite, schist and slate with varying $\theta$ angle

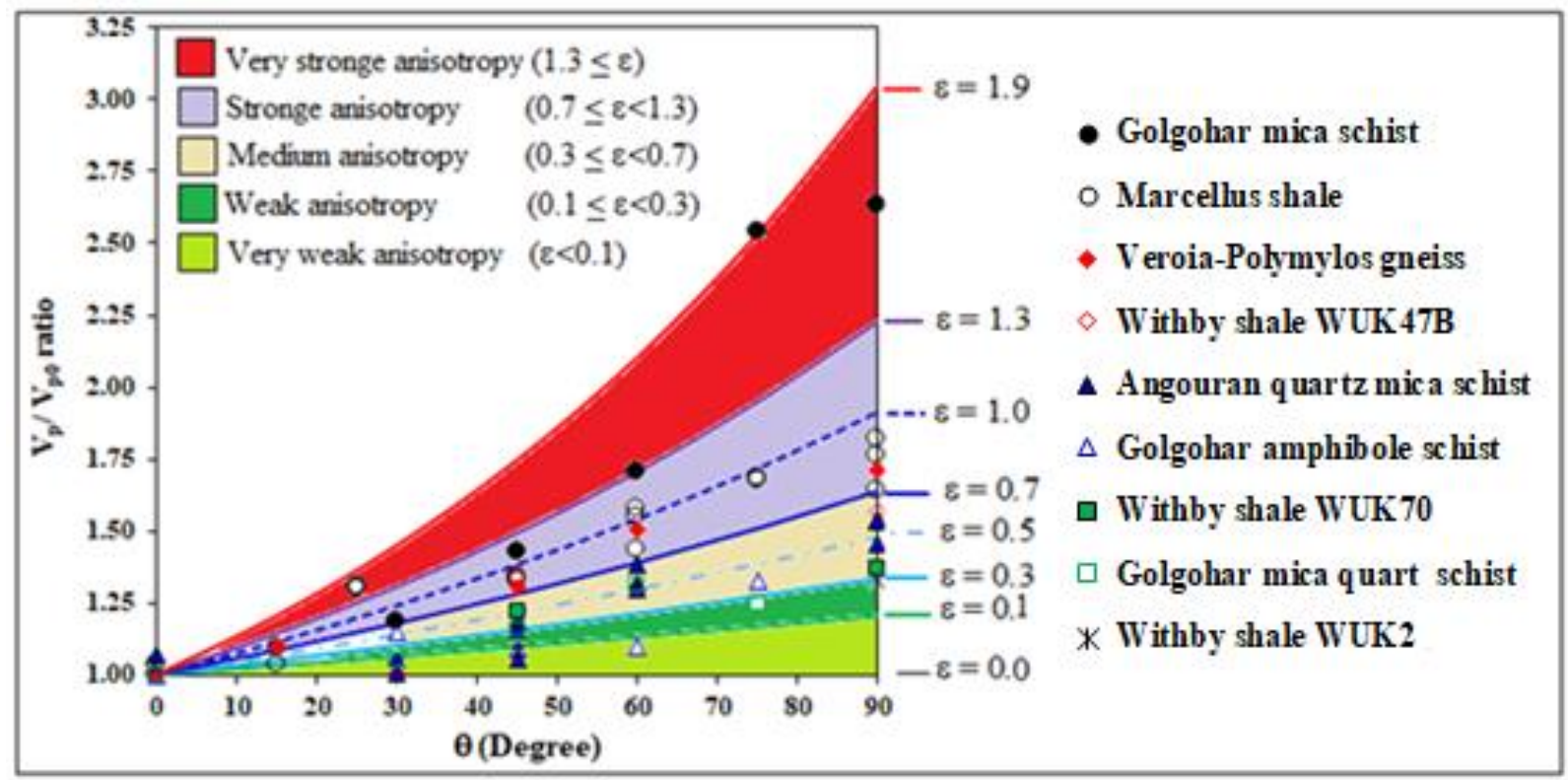

Fig. 14 Classifiction of $V_{P}$ anisotropy based on different values of $\varepsilon$ 


\section{Conclusions}

1. The results showed that the $V_{P}$ anisotropy of rock texture in quartz-mica schist is stronger than the $V_{P}$ anisotropy of jointed rock. That is because all body of quartz-mica schist specimens have textural anisotropy hence $V_{P}$ anisotropy behaviour.

2. The obtained relation between $V_{P}$ and $\theta$ angle with expontial function has a good fit to different groups of results and coffecent $\mathrm{K}$ of the expontial function (Eq. 14) varies from one group of results to another and it has signficant corelation with $\varepsilon$ value. The developed expontial function is signficantly fitted to different groups of results having different $\varepsilon$ values. $V_{P}$ anisotropy can simply be predicted by the developed relation using only two parameters of $\mathrm{V}_{\mathrm{P} 0}$ and $\mathrm{V}_{\mathrm{P} 90}$ or $\varepsilon$ value $\left.\left.\left[\varepsilon=\mathrm{V}_{\mathrm{P} 90}-\mathrm{V}_{\mathrm{P} 0}\right) / \mathrm{V}_{\mathrm{P} 0}\right)\right]$.

3. A new $V_{P}$ anisotropy classfication was also devloped using a wide range $V_{P}$ anisotropy results and abtained new relation in this study. $V_{P}$ anisotropy as a function of $\theta$ angle varies in five classes including: very weak anisotropy $(\varepsilon<0.1)$, weak anisotropy $(0.1 \leq \varepsilon<0.3)$, medium anisotropy $(0.3 \leq \varepsilon<0.7)$, strong anisotropy $(0.7 \leq \varepsilon<0.1 .3)$ and very strong anisotropy $(1.3 \leq \varepsilon)$ values (Fig. 11).

\section{References}

Anderson, D.L,, Minster, B., Cole, D., 1974. The effect of oriented cracks on seismic velocities. J Geophysics Res 79: 1974; 4011-4015

Babuska V (1981) Anisotropy of $\mathrm{V}_{\mathrm{p}}$ and $\mathrm{V}_{\mathrm{s}}$ in rock-forming minerals. J Geophysics. 1981; 50:1-6

Backus GE (1962) Long-wave elastic anisotropy produced by horizontal layering. J Geophysics Res 67: 442; 7-4440

Barton N, 2007. Rock quality, seismic velocity, attenuation and anisotropy, Taylor \& Francis Group, London, UK, 756 pages

Ben Ismaïl W, Mainprice D (1998) Mainprice, An olivine fabric database: an overview of upper mantle fabrics and seismic anisotropy, Tectonophysics, 296:145-157

Cardenes V, Lopez-Sanchez MA, Barou F, Olona J, Llana-Fúnez S (2021) Crystallographic preferred orientation, seismic velocity and anisotropy in roofing slates. Tectonophysics Vol. 808. https://doi.org/10.1016/j.tecto.2021.228815

Crampin S, Bamford D (1977) Inversion of P-wave velocity anisotropy. Geophys J Intl. 49:123-132.

Crampin S, Kirkwood SC (1981) Velocity variation in systems of anisotropic symmetry. J Geophysics 49:35-42

Crampin S, McGonigl R, Bamford D (1980) Estimating crack parameters from observations of P-wave velocity anisotropy. Geophysics 46:345-360

Cholach, P.Y., Schmitt, D.R., 2006. Intrinsic elasticity of a textured transversely isotropic muscovite aggregate: Comparisons to the seismic anisotropy of schists and shales. J Geophys Res 111:410-427.

Hajiheidari F, Karimi Nasab S, Rahmani M, Zare H (2016) Investigation of the strength anisotropy to ssess strength properties rock in Golgohar Iron Mine No. 1, Searcher Quarterly Journal, (12)1-6 
Heidari M, Ajalloeian R, Ghazifard A et al. (2020) Evaluation of P and S Wave Velocities and Their Return Energy of Rock Specimen at Various Lateral and Axial Stresses. Geotechnical and Geological Engineering 38:32533270. https://doi.org/10.1007/s10706-020-01221-9

ISRM (1978) Suggested methods for determining sound velocity, International Society for Rock Mechanics Commission on Standardization of Laboratory and Field Tests, International Journal of Rock Mechanics and Mining Sciences and Geomechanics Abstracts, 15:53-58

Jin ZF, Li WX, Jin C, James H Cusatis G (2018) Anisotropic elastic, strength, and fracture properties ofMarcellus shale, International Journal of RockMechanics andMining Sciences, 109:124-137

Kern H (1978) The effect of high temperature and high confining pressure on compressional wave velocities in quartzbearing and quartz-free igneous and metamorphic rocks. ' Tectonophysics, 44:185 - 203

Kern H (1990) Laboratory seismic measurements: an aid in the interpretation of seismic field data. Terra Nova 2, 617628

Kim H, Cho JW, Song I, Min KB (2012) Anisotropy of elastic moduli, P-wave velocities and thermal conductivities of Asan Gneiss Boryeong Shale and Yeoncheon Schist in Korea. Eng. Geol. 147: 68-77

Li X, Lei X, Li Q (2018) Response of Velocity Anisotropy of Shale Under Isotropic and Anisotropic Stress Fields. Rock Mech Rock Eng 51:695-711. https://doi.org/10.1007/s00603-017-1356-2

Liu J, Dai G, Gong W (2021) Joint Frequency in the Rock Mass Rating 2014 Classification System Based on Field P-wave Propagation Velocity Tests: A New Rating Method. Geotechnical and Geological Engineering https://doi.org/10.1007/s10706-021-01777-0

Ma T, Peng N, Zhu Z, Zhang Q, Yang C, Zhao J (2018) Brazilian tensile strength of anisotropic rocks: review and new insights. Energies 11:304. https://doi.org/10.3390/en11020304

Nur A (1971) Effects of stress on velocity anisotropy in rocks with cracks. Geophysical research 76:2022-2034

Palmer D (2001) Measurement of rock fabric in shallow refraction seismology. Exploration Geophysics 32:307-314

Patella D, Patella SD (2009) Geophysical tomography in engineering geological applications: A mini-review with examples. The open geology journal 3:30-38.

Ramamurthy T (2008) Joint factor concept in solving rock engineering problems, 5th Asian Rock Mechanics Symposium (ARMS5), Tehran, Iran, 147 - 156.

Rezaei M, Koureh Davoodi P, Najmoddini I (2019) Studying the correlation of rock properties with P-wave velocity index in dry and saturated conditions. Journal of Applied Geophysics, Volume 169: 49-57 https://doi.org/10.1016/j.jappgeo.2019.04.017

Saroglou H, Marinos P, Tsiambaos G., 2004. The anisotropic nature of selected metamorphic rocks from Greece, The South African Institute of Mining and Metallurgy, 217 - 222.

Sarout J, Gueguen Y (2008) Anisotropy of elastic wave velocities in deformed shales: Part 1 - experimental results, Geophysics, 73:75-89

Song I Suh M (2014) Effects on foliation and microcracks on ultrasonic anisotropy in retrograde ultramafic and metamorphic rocks at shallow depths. Journal of Applied Geophysics 109:27-35 
Takanashi M, Nishizawa O, Kanagawa K, Yasunaga K (2001) Laboratory measurements of elastic anisotropy parameters for the exposed crustal rocks from the Hidaka metamorphic belt, Central Hokkaido Japan. Geophys J Intl 145:33-47.

Tatham RH (1982) Vp / Vs and Lithology. Geophysics 47:336-344

Thomsen L (1986) Weak elastic anisotropy. J Geophysics 51:1954 - 1966.

Tsidzi KEN (1997) Propagation characteristics of ultrasonic waves in foliated rocks. IAEG Bulletin, 56:103-113

Tsvankin I (1997) Anisotropic parameters and P-wave velocity for orthorhombic media. J of Geophysics 62:12921309

Wang R, Deng X, Meng Y et al. (2020) Application of Ultrasonic-Rebound Method in Fast Prediction of Rock Strength. Geotechnical and Geological Engineering 38, 5915-5924. https://doi.org/10.1007/s10706-02001402-6

Winterstein DF (1990) Velocity anisotropy terminology for geophysicist. Geophysics 55:1070-1088

Xu F, Yang C, Guo Y et al. (2017) Effect of bedding planes on wave velocity and AE characteristics of the Longmaxi shale in China. Arab J Geosci 10, 141, https://doi.org/10.1007/s12517-017-2943-y

Zhang ZP, Wong LNY, Wang SJ, Han GY (2011) Engineering properties of quartz-mica schist, Engineering Geology, 121:135-149. doi:10.1016/j.enggeo.2011.04.020

Zhubayev A, Houben ME, Smeulders DMJ, Barnhoorn A (2016) Ultrasonic velocity and attenuation anisotropy of shales, Whitby, United Kingdom, Geophysics, 81:45-56 
Figures

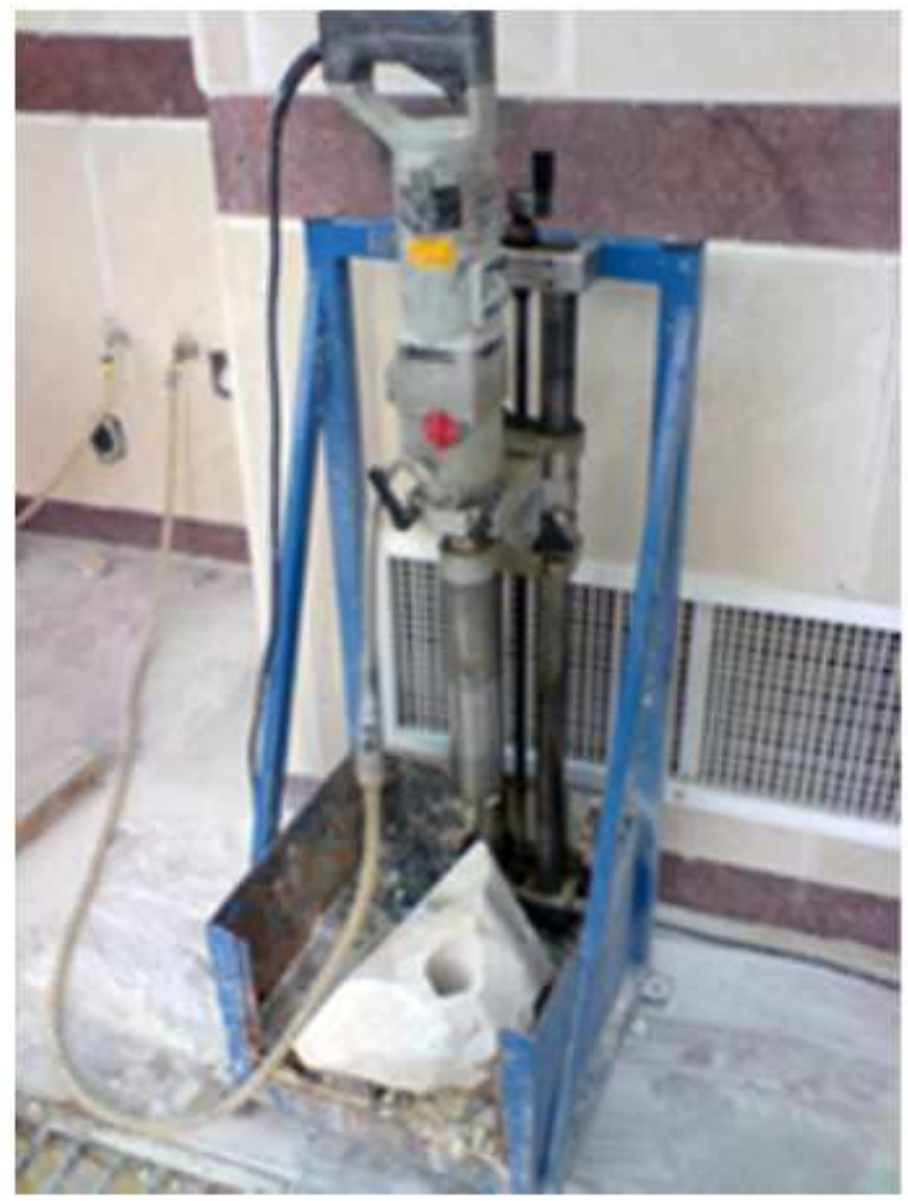

Figure 1

Core drilling machine 


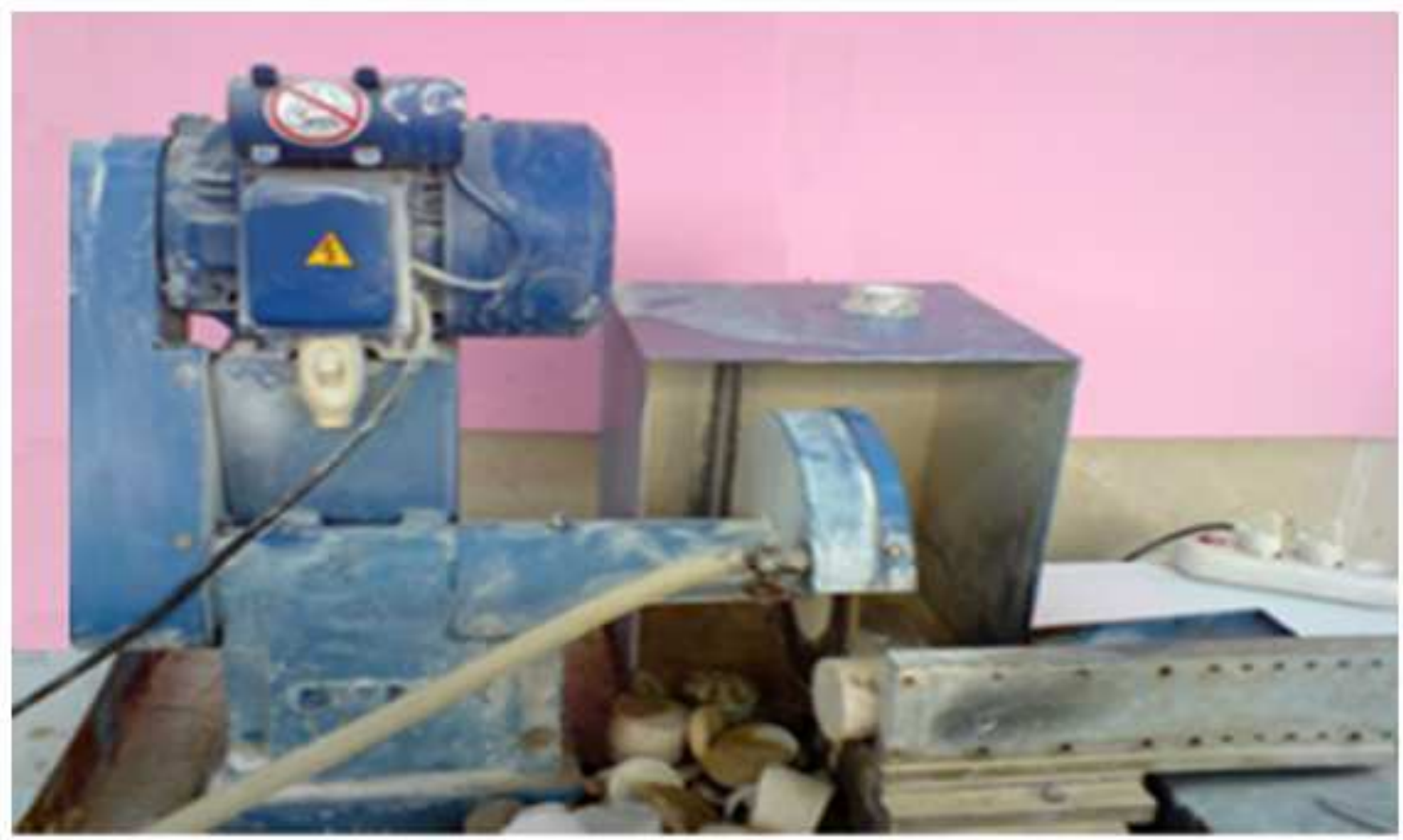

Figure 2

Core cutting machine

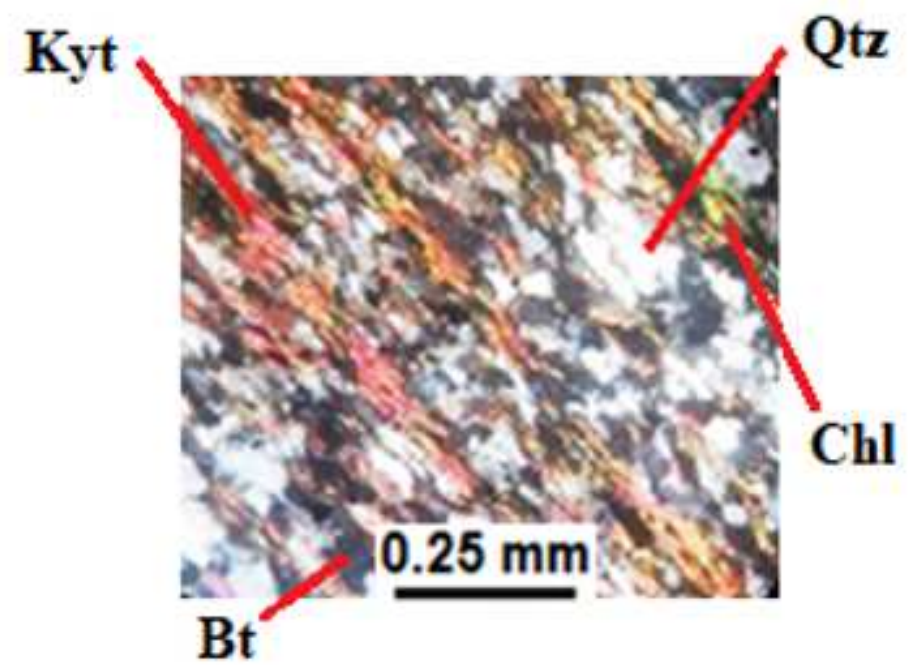

\section{Figure 3}

Microscopic XPL picture of the well foliated schistosity in a specimen containg Biotite (Bt), Chlorite (Chl), Quartz (Qtz) and Kyanite (Kyt). 


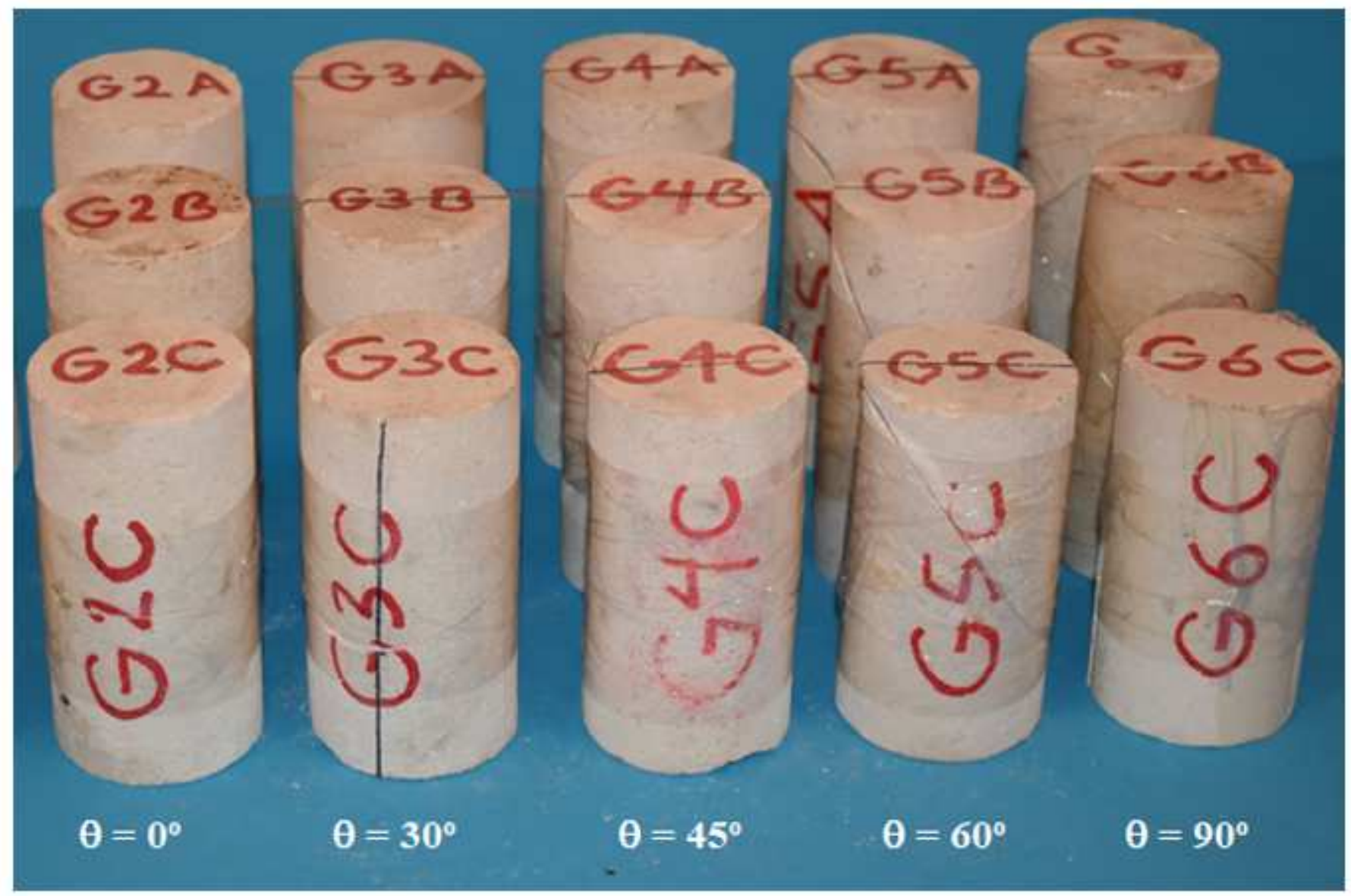

\section{Figure 4}

The prepared jointed Naqadeh limestone specimens with orientation angles $(\theta)$ 0, 30, 45, 60 and 90 degrees

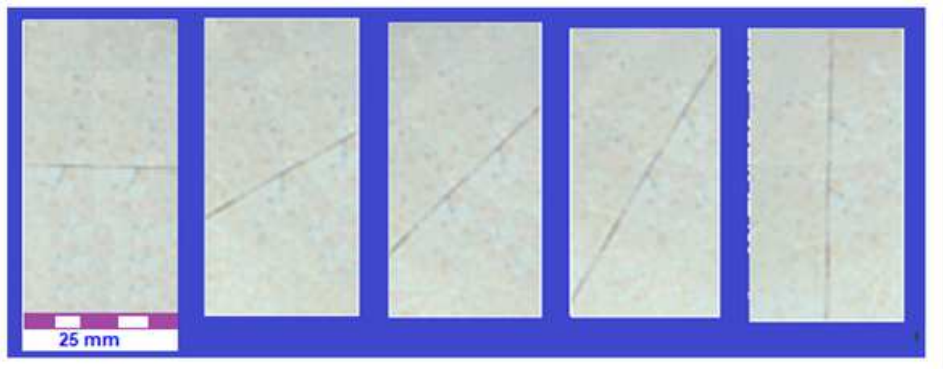

$\theta=0^{\circ}$

$\theta=30^{\circ}$

$\theta=45^{\circ}$

$\theta=60^{\circ} \quad \theta=90^{\circ}$

A) Jointed Naqadeh limestone

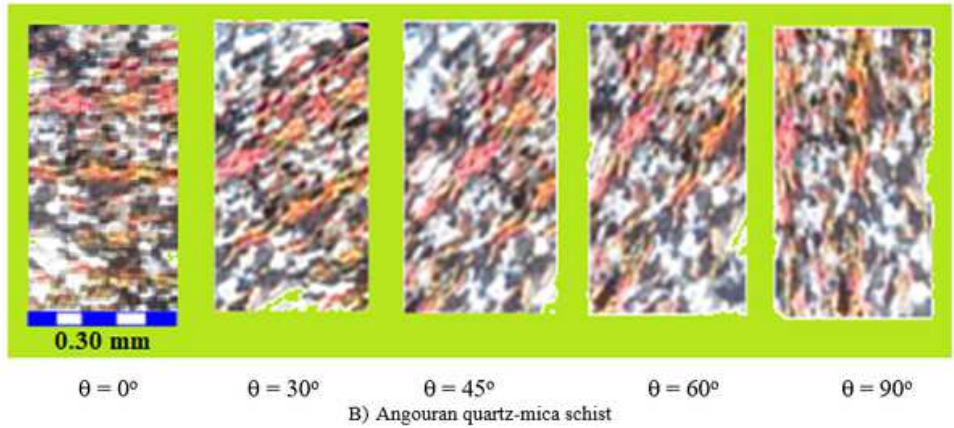

Figure 5

The of microscopic pictures of orientaion angles in well foliated schistosity in Angouran quartz-mica schist and jointed Naqadeh limestone specimens 


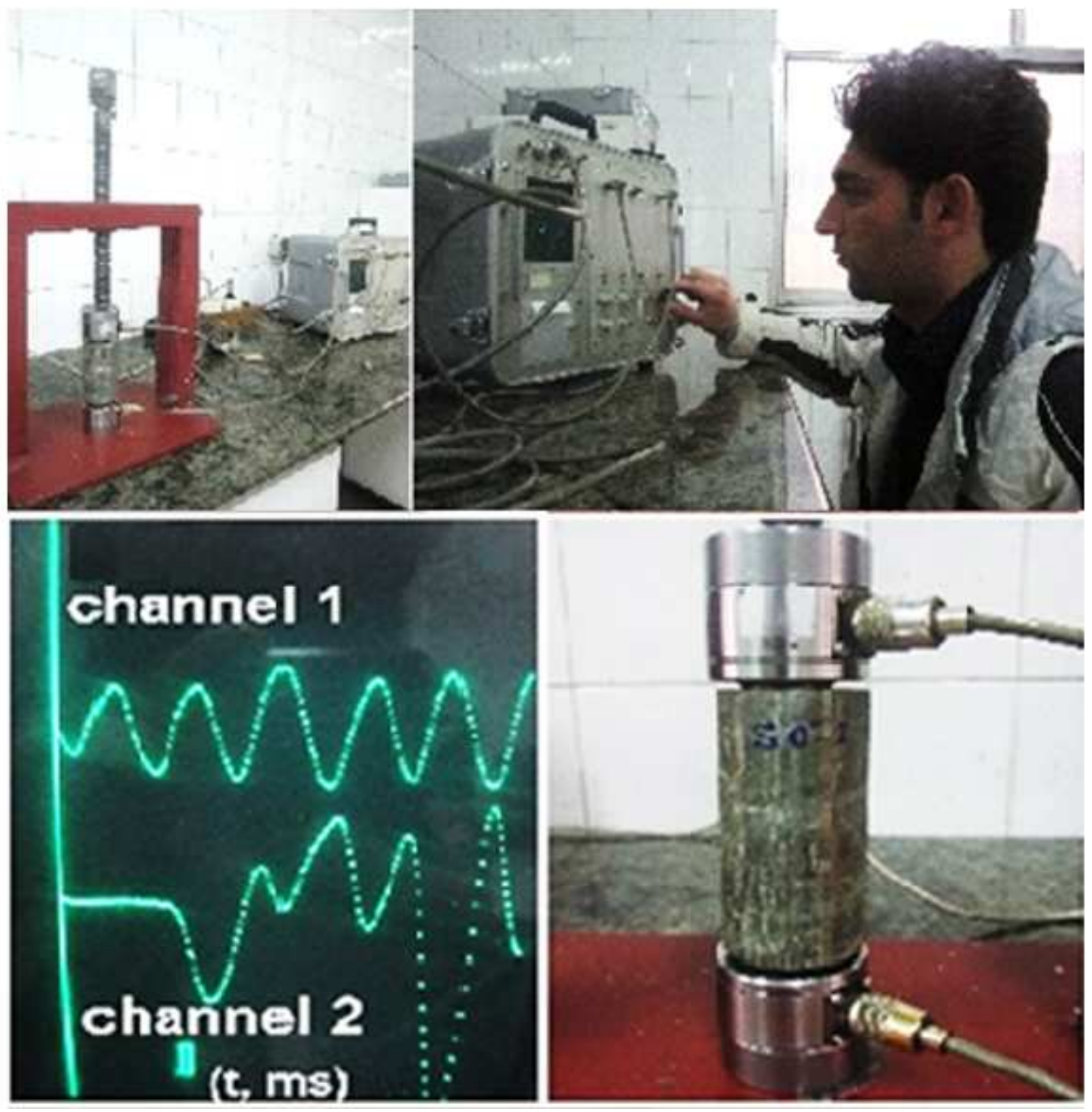

Figure 6

Testingt equipment of ultrasonic wave velocity system 


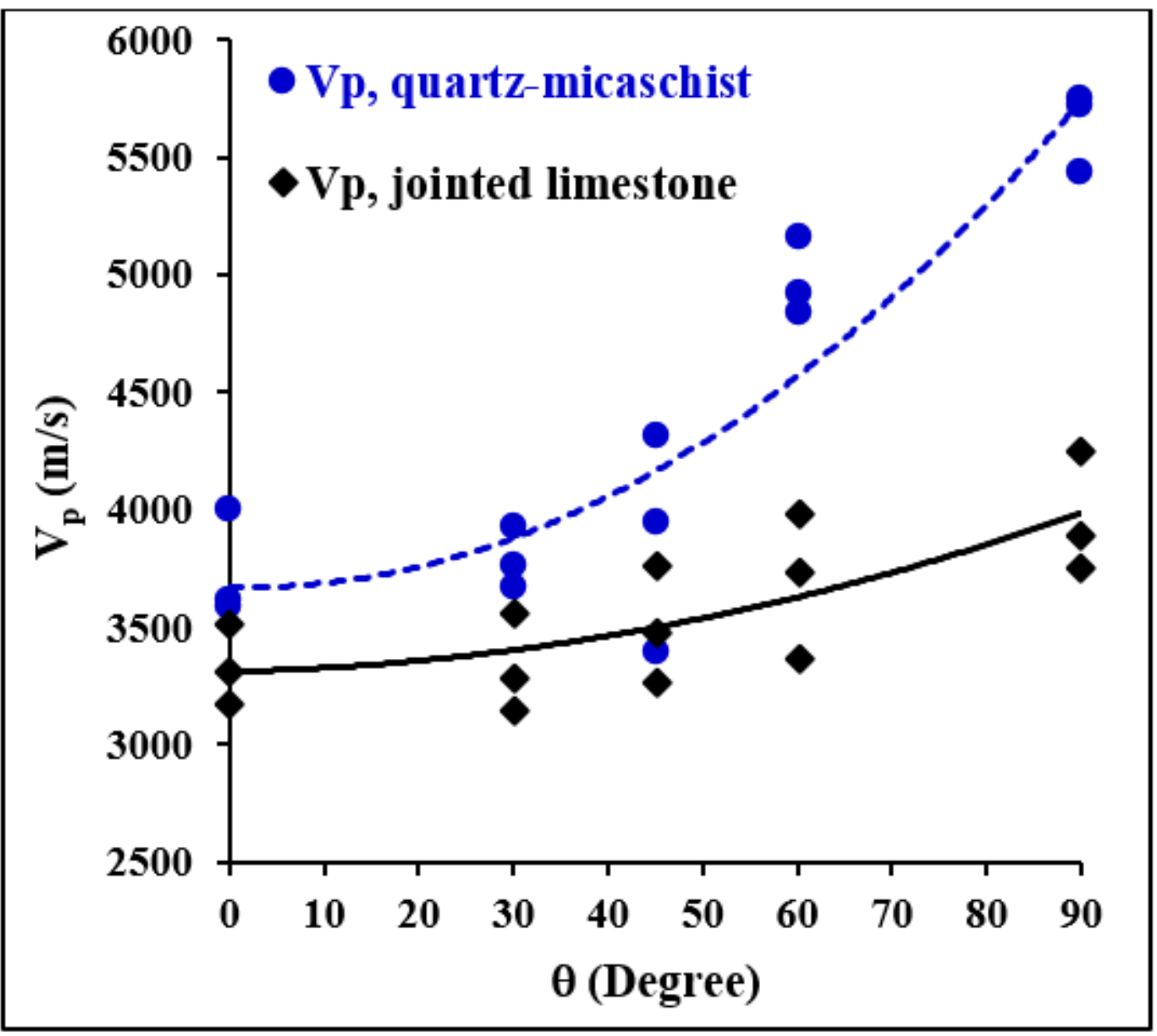

Figure 7

Comparison between P-wave velocity anisotropy in quartz-mica schist and jointed limestone specimens 


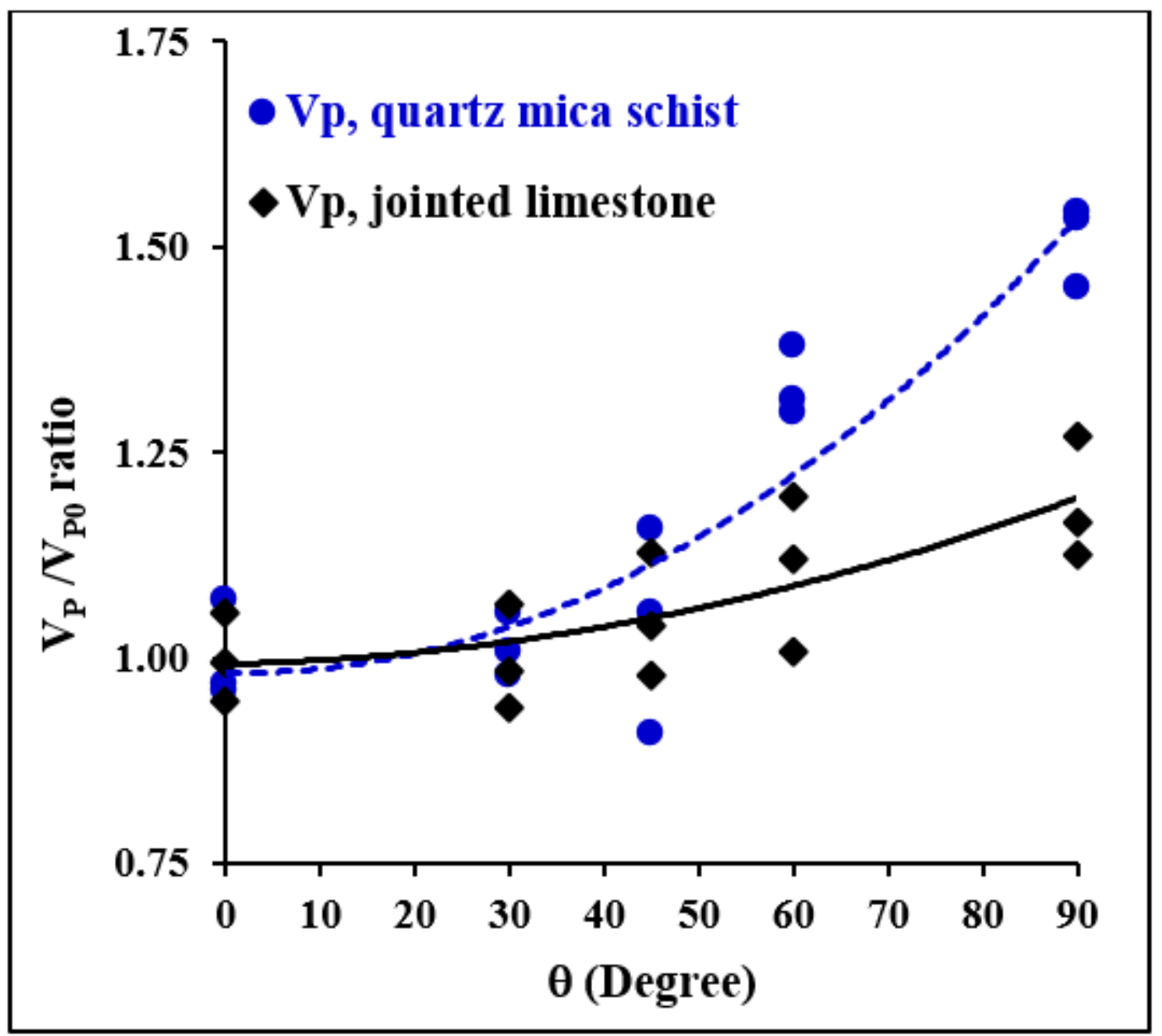

Figure 8

Comparison between effect $\theta$ angle on VP/VP0 ratio in quartz-mica schist and jointed limestone specimens 


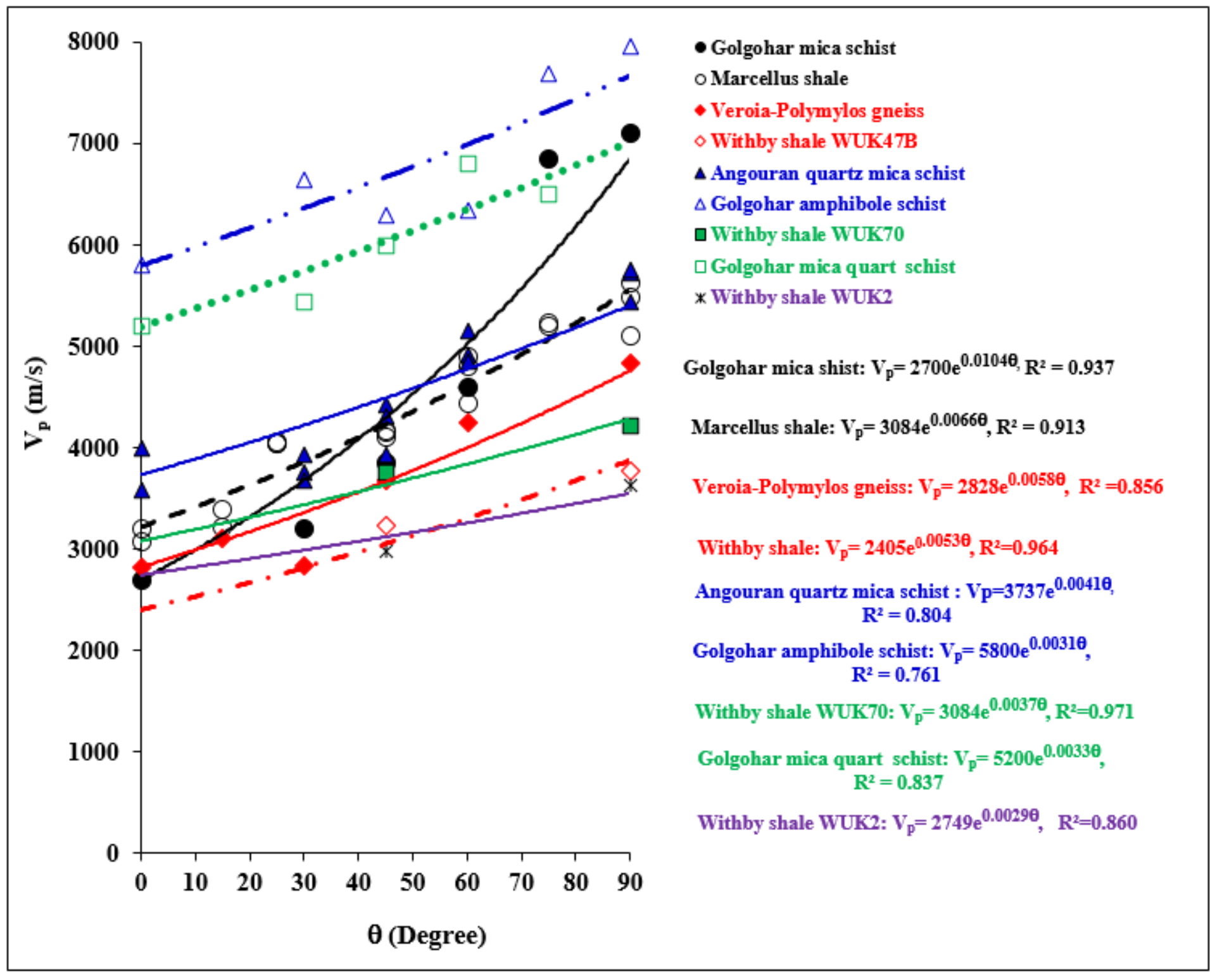

Figure 9

The best fuction fit to the relation between VP and $\theta$ angle for different types of rocks 


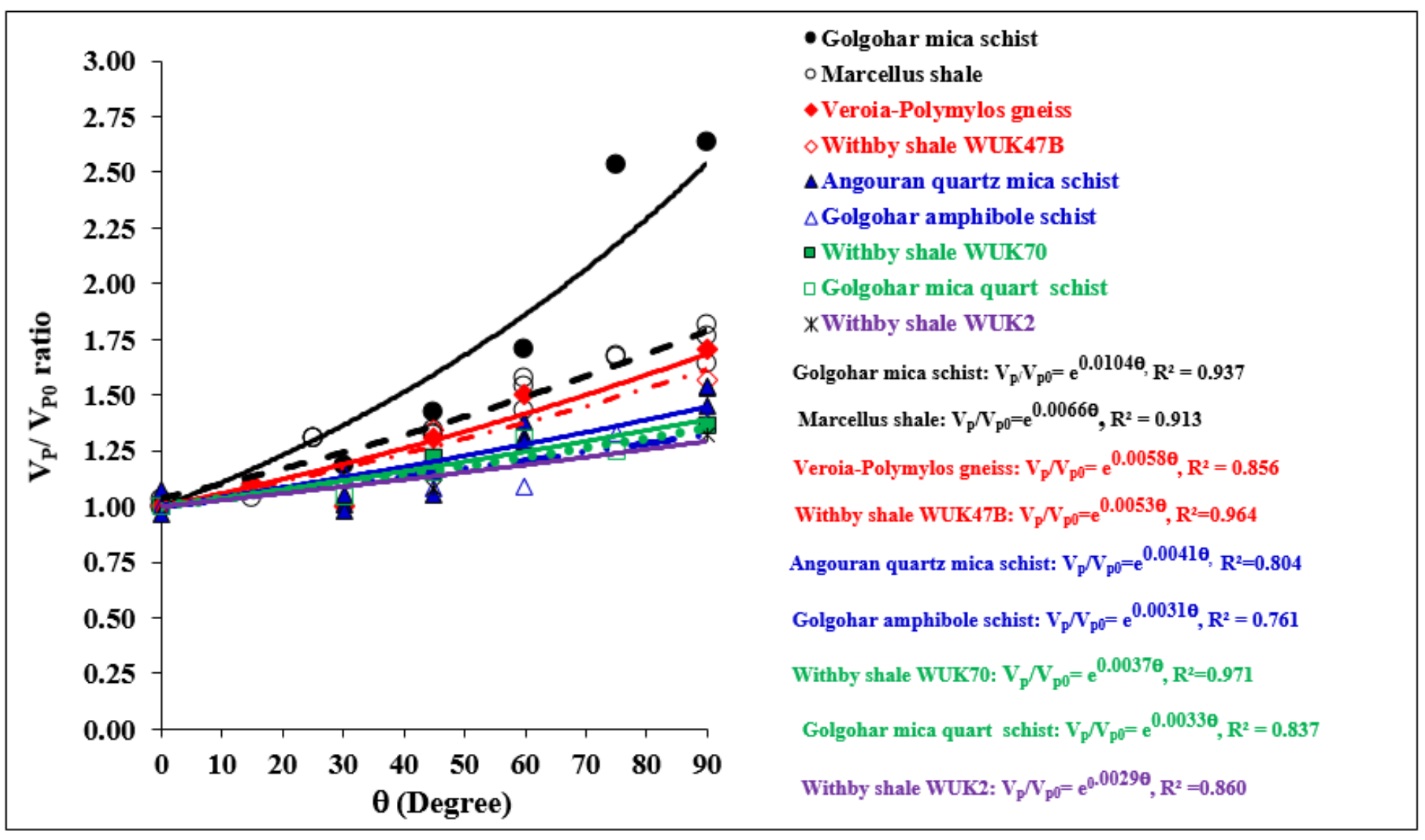

Figure 10

Relation between VP/VP0o ratio and $\theta$ angle for different types of rocks

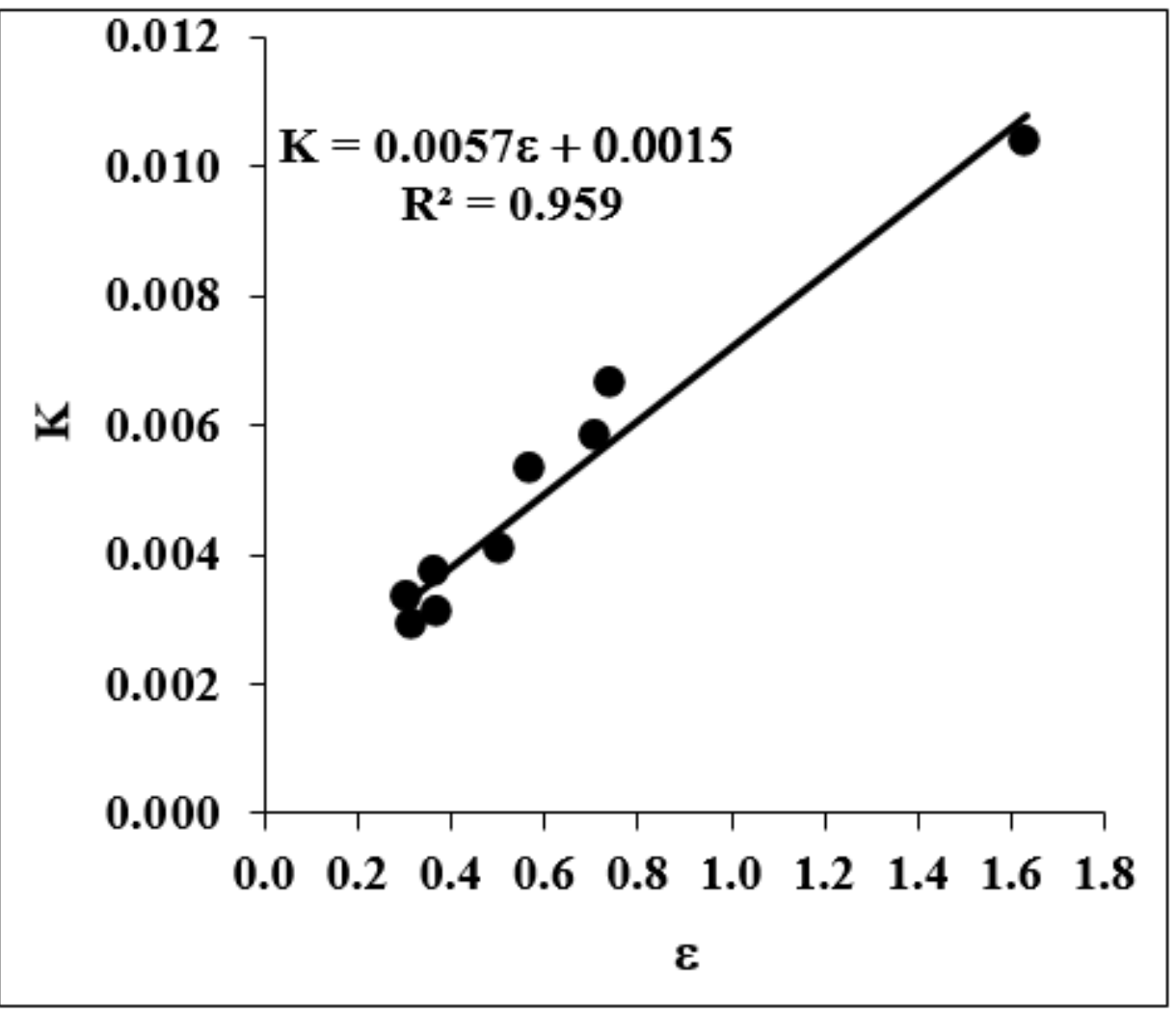


Figure 11

Relation between coefficients $\mathrm{K}$ and $\varepsilon$ for different types of rocks

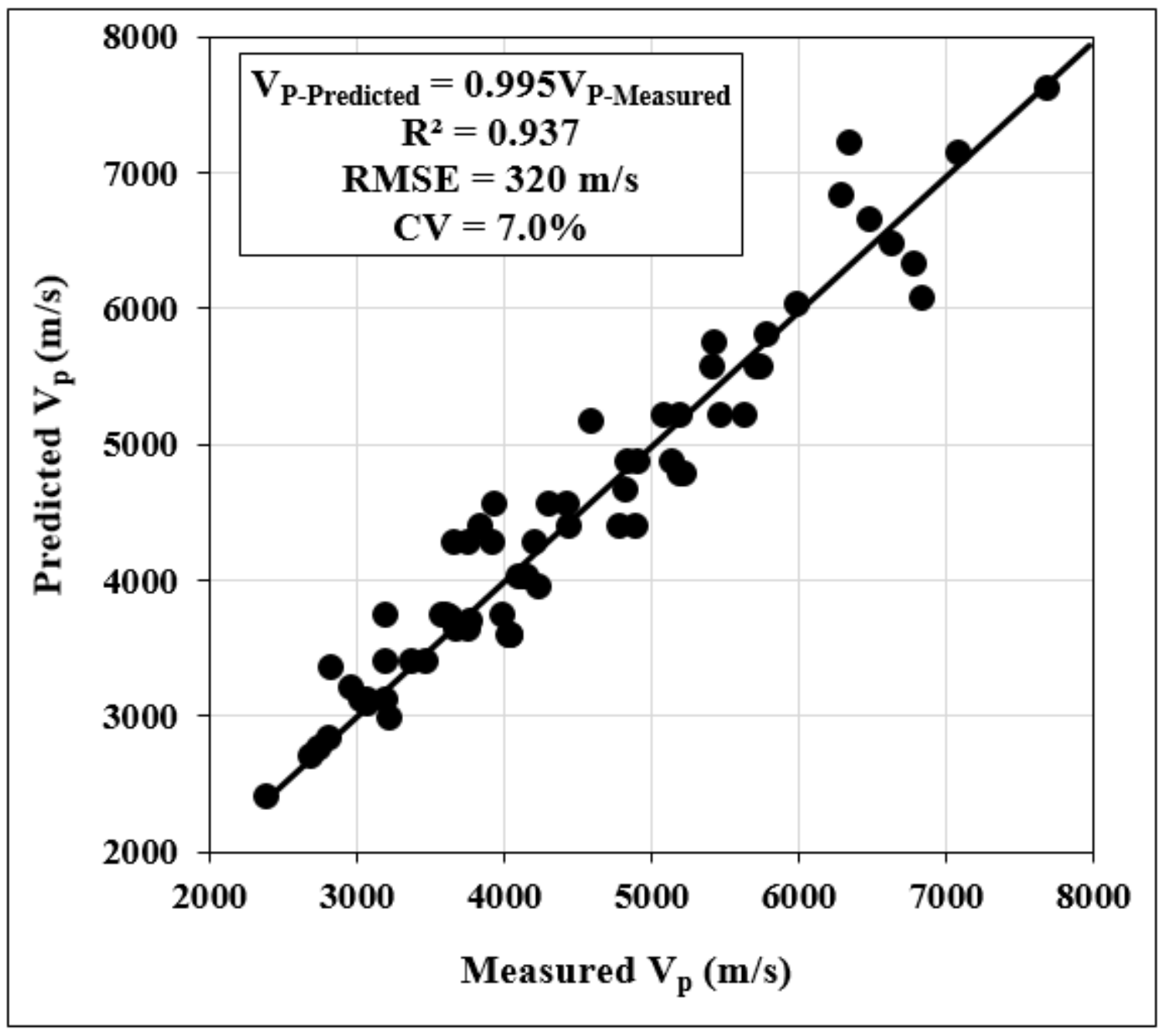

Figure 12

Comparison between predicted VP and measured VP for different groups of results 


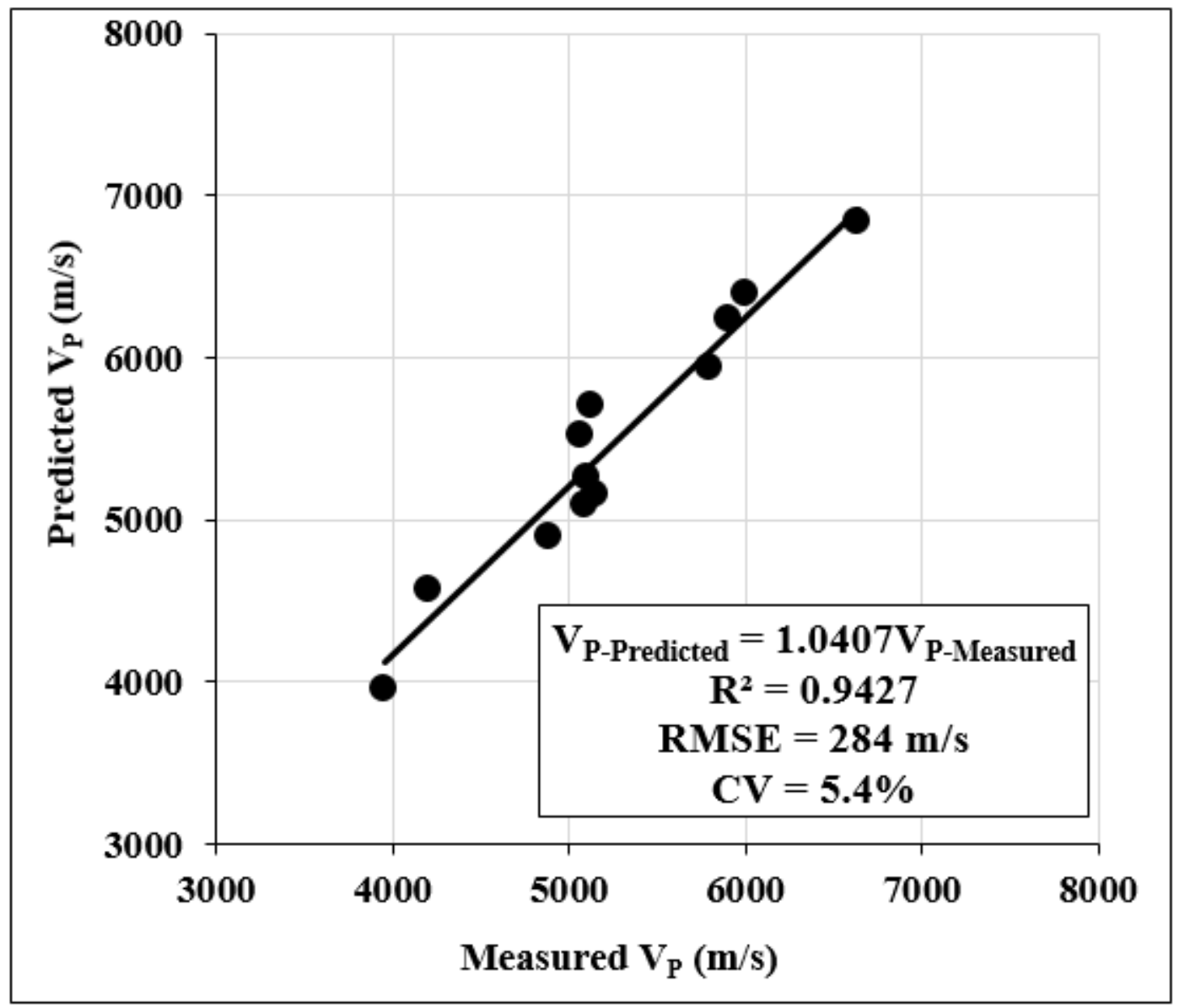

Figure 13

Validation of predicted VP by the developed relation and the meaured VP of gneiss, phyllite, schist and slate with varying $\theta$ angle 


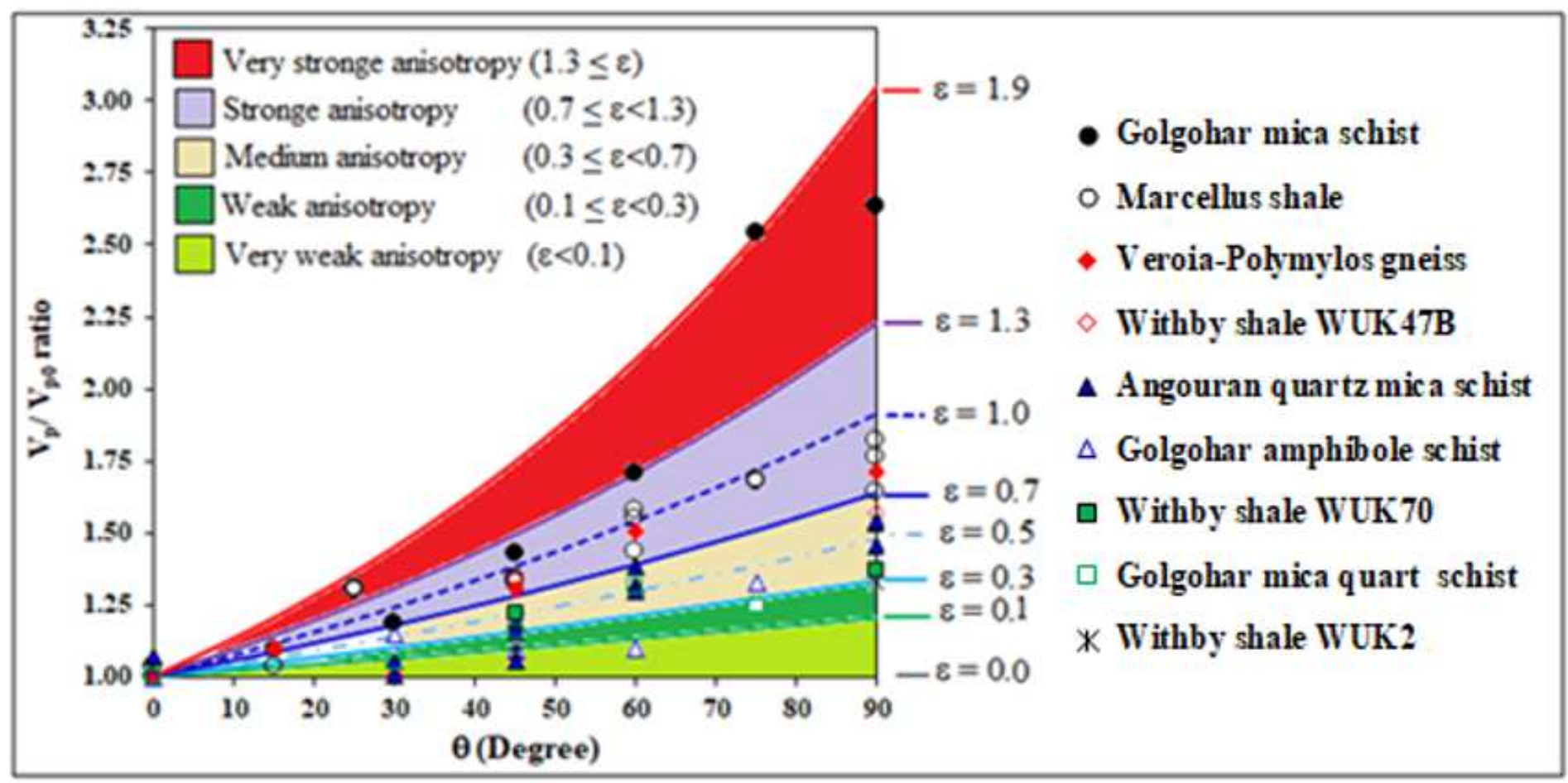

Figure 14

Classifiction of VP anisotropy based on different values of $\varepsilon$ 